\title{
TESTING OF THE SEMIKRON VALIDATION AIPM UNIT AT THE OAK RIDGE NATIONAL LABORATORY - JANUARY 2005
}

Prepared by:

Oak Ridge National Laboratory

Mitch Olszewski, Program Manager

Submitted to:

Energy Efficiency and Renewable Energy

FreedomCAR and Vehicle Technologies

Vehicle Systems Team

Susan A. Rogers, Technology Development Manager

March 2005 
NATIONAL LABORATORY

MANAGED BY UT-BATTELLE

FOR THE DEPARTMENT OF ENERGY

\section{Engineering Science \& Technology Division}

\author{
TESTING OF THE SEMIKRON \\ VALIDATION AIPM UNIT AT THE \\ OAK RIDGE NATIONAL LABORATORY \\ JANUARY 2005
}

\author{
S. C. Nelson \\ C. W. Ayers
}

Publication Date: March 2005

Prepared by the

OAK RIDGE NATIONAL LABORATORY

Oak Ridge, Tennessee 37831 managed by

UT-BATTELLE, LLC

for the

U.S. DEPARTMENT OF ENERGY

Under contract DE-AC05-00OR22725 
This report was prepared as an account of work sponsored by an agency of the United States Government. Neither the United States Government nor any agency thereof, nor any of their employees, makes any warranty, express or implied, or assumes any legal liability or responsibility for the accuracy, completeness, or usefulness of any information, apparatus, product, or process disclosed, or represents that its use would not infringe privately owned rights. Reference herein to any specific commercial product, process, or service by trade name, trademark, manufacturer, or otherwise, does not necessarily constitute or imply its endorsement, recommendation, or favoring by the United States Government or any agency thereof. The views and opinions of authors expressed herein do not necessarily state or reflect those of the United States Government or any agency thereof. 


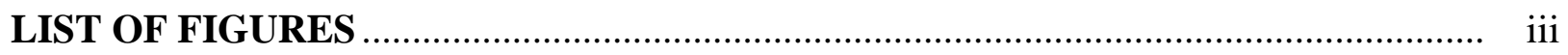

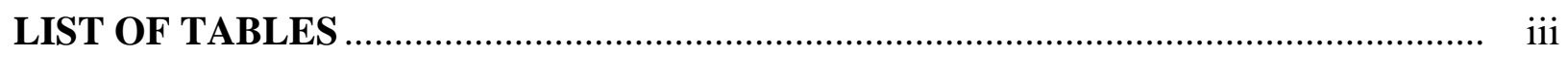

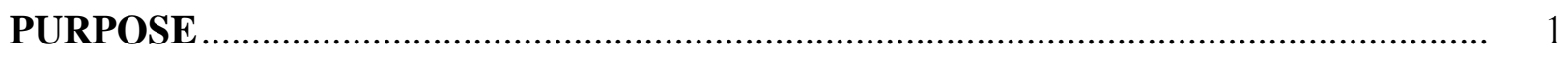

DESCRIPTION OF THE AIPM UNIT ...................................................................

DESCRIPTION OF TESTS.....................................................................................

Inductive Load Testing ........................................................................................... 1

Dynamometer Testing ....................................................................................... 11

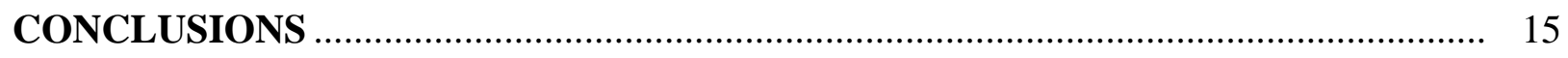

\section{APPENDIX A: AUTOMOTIVE INTEGRATED POWER MODULE (AIPM)}

TEST PLAN

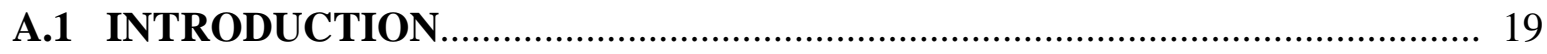

A.2 INITIAL ELECTRICAL TEST (CHARACTERIZATION) ………………..... 20

A.2.1 Receipt of DUT ……………......................................................... 20

A.2.2 Electrical Tests on Bench ……………............................................... 20

A.2.2.1 Isolation impedance ..................................................................... 20

A.2.2.2 Inductive load test ....................................................................... 20

A.2.2.2.1 Minimal dc link voltage test with inductive load ........... 20

A.2.2.2.2 Maximum dc link voltage test with inductive load ....... 20

A.2.2.2.3 Nominal voltage test with inductive load ...................... 20

A.2.2.2.4 Continuous power test ................................................... 21

A.2.2.2.5 Peak power test ............................................................. 21

A.2.3 Electrical Test on Dynamometer System …………….............................. 21

A.2.3.1 Nominal battery voltage ………………………........................................ 21

A.3 TEST SETUP SUMMARY …………………............................................. 21

APPENDIX B: RECOMMENDED AIPM AND AEMD SPECIFICATIONS ................ 22

APPENDIX C: EQUIPMENT USED IN TESTING AIPM ………........................... 23 
1 Top view of Semikron AIPM unit................................................................................ 2

2 Control computer, power meter, power supply, and Semikron unit ............................ 3

3 CAN bus display ………………............................................................................... 3

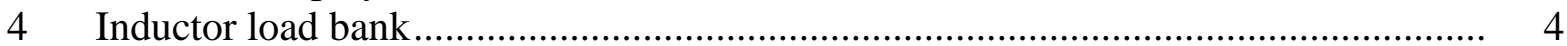

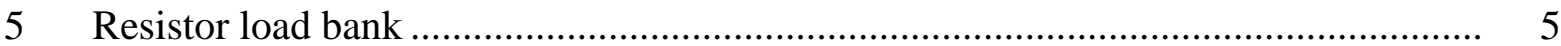

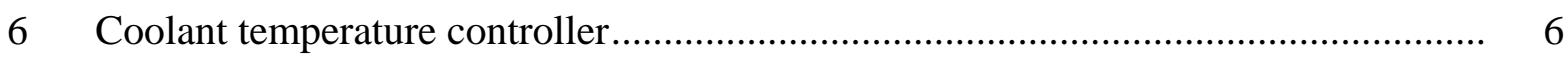

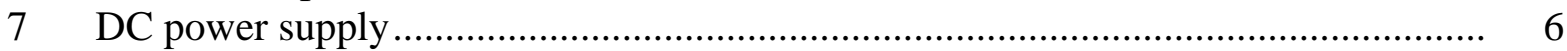

8 Power meter readings and current waveforms at end on continuous power test......... 10

9 Power meter readings and current waveforms at end on peak power test................... 11

10 Inverter efficiency vs. output power...................................................................... 12

11 Inverter efficiency vs. motor speed .......................................................................... 12

12 Semikron inverter phase current vs. torque.............................................................. 14

13 Semikron inverter efficiency vs. speed at continuous power..................................... 14

14 Power meter readings and current waveforms during continuous power test on dyne ........................................................................................................ 15

15 View of dynamometer test cell from control room .............................................. 17

16 Load motor and 100-hp dynamometer ..................................................................... 18

Table

\section{LIST OF TABLES}

1 Short duration testing of Semikron inverter with 200 Vdc link .................................. 7

2 Short duration testing of Semikron inverter with 250 Vdc link ................................... 7

3 Short duration testing of Semikron inverter with 400 and 450 Vdc link .................... 8

4 Short duration testing of Semikron inverter with 325 Vdc link .................................. 9

5 Continuous power testing of Semikron inverter with $325 \mathrm{Vdc}$ link............................ 10

$6 \quad$ Testing of Semikron inverter at greater than continuous power levels ........................ 10

$7 \quad$ Dynamometer testing of Semikron inverter-speed vs. inverter efficiency................ 13

$8 \quad$ Specific power density summary ........................................................................... 16 


\section{PURPOSE}

This report documents the electrical tests performed on the Semikron high-voltage automotive integrated power module (AIPM) at the Oak Ridge National Laboratory (ORNL). Testing was performed with an inductive/resistive load and with a motor load at the National Transportation Research Center (NTRC) during the second quarter of FY 2005.

\section{DESCRIPTION OF THE AIPM UNIT}

The Semikron inverter (Serial Number 0430 129-AD) is a validation unit developed for hybrid electric vehicle (HEV) traction drive applications. The AIPM was designed to operate with a nominal dc link voltage of $325 \mathrm{Vdc}$ with a minimum and maximum dc link voltage of 200 and $450 \mathrm{Vdc}$, respectively. The inverter has been constructed with 600-V, 400-A insulated gate bipolar transistors (IGBTs). The unit utilizes a CAN interface for communications and has integrated current sensors. The unit has over-current, over-voltage, and over-temperature protection. The inverter is liquid cooled with coolant flow rate of $10 \mathrm{~L} / \mathrm{min}$.

The unit weighs approximately $17 \mathrm{lbs}(7.7 \mathrm{~kg})$. The unit is roughly rectangular in shape, but has irregular dimensions. The maximum length, including mounting flanges and hose connections, is 17.6 in. $(449 \mathrm{~mm})$. Excluding the mounting flanges and hose connections, the unit measures $16.1 \mathrm{in} .(410 \mathrm{~mm})$. The maximum width of the unit is $8.2 \mathrm{in} .(210 \mathrm{~mm})$ and the minimal width is 7.2 in. $(185 \mathrm{~mm})$. The maximum height of the unit is about 4 in. $(100 \mathrm{~mm})$. The volume of the unit is approximately 6.9 liters.

\section{DESCRIPTION OF TESTS}

The AIPM unit was visually inspected, measured, and weighed after the unit arrived at ORNL (January 2005). The isolation between the input and output terminals (i.e., dc link and phase voltage terminals) was checked with a digital volt meter prior to the testing. The minimal isolation was greater than $1 \mathrm{Mohm}$.

The unit was tested per the AIPM test plan (see Appendix A). The AIPM specification is contained in Appendix B. The equipment used in the testing is listed in Appendix C.

\section{Inductive Load Testing}

The initial testing of the inverter was performed in the Power Electronics' laboratory, room L101, of the NTRC building with an inductive/resistive load. The load was connected in a Y-arrangement with an inductor and a resistor connected in series for each leg. Figure 1 shows a top view of the Semikron AIPM unit being load tested. Figure 2 shows the notebook computer used to run the control software, the Yokogawa power meter, and the power supply for the Semikron controller. The Semikron inverter is in the background in Fig. 2. Figure 3 shows a more detailed view of the CAN bus display (graphical user interface). Figures 4 and 5 show the inductive and resistive load banks. Figure 6 shows the coolant temperature controller, and Fig. 7 shows the dc power supply. 


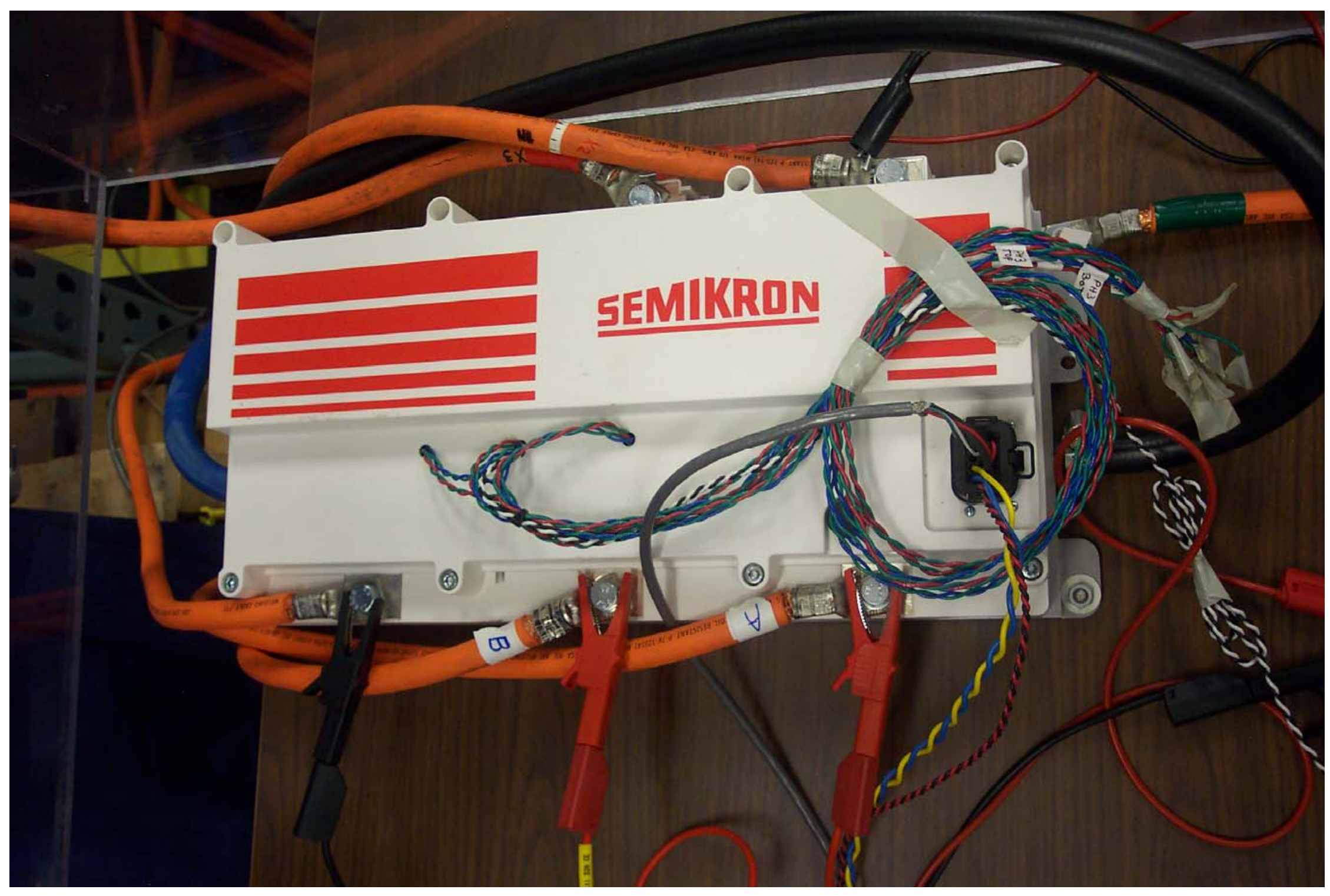

Fig. 1. Top view of Semikron AIPM unit. 


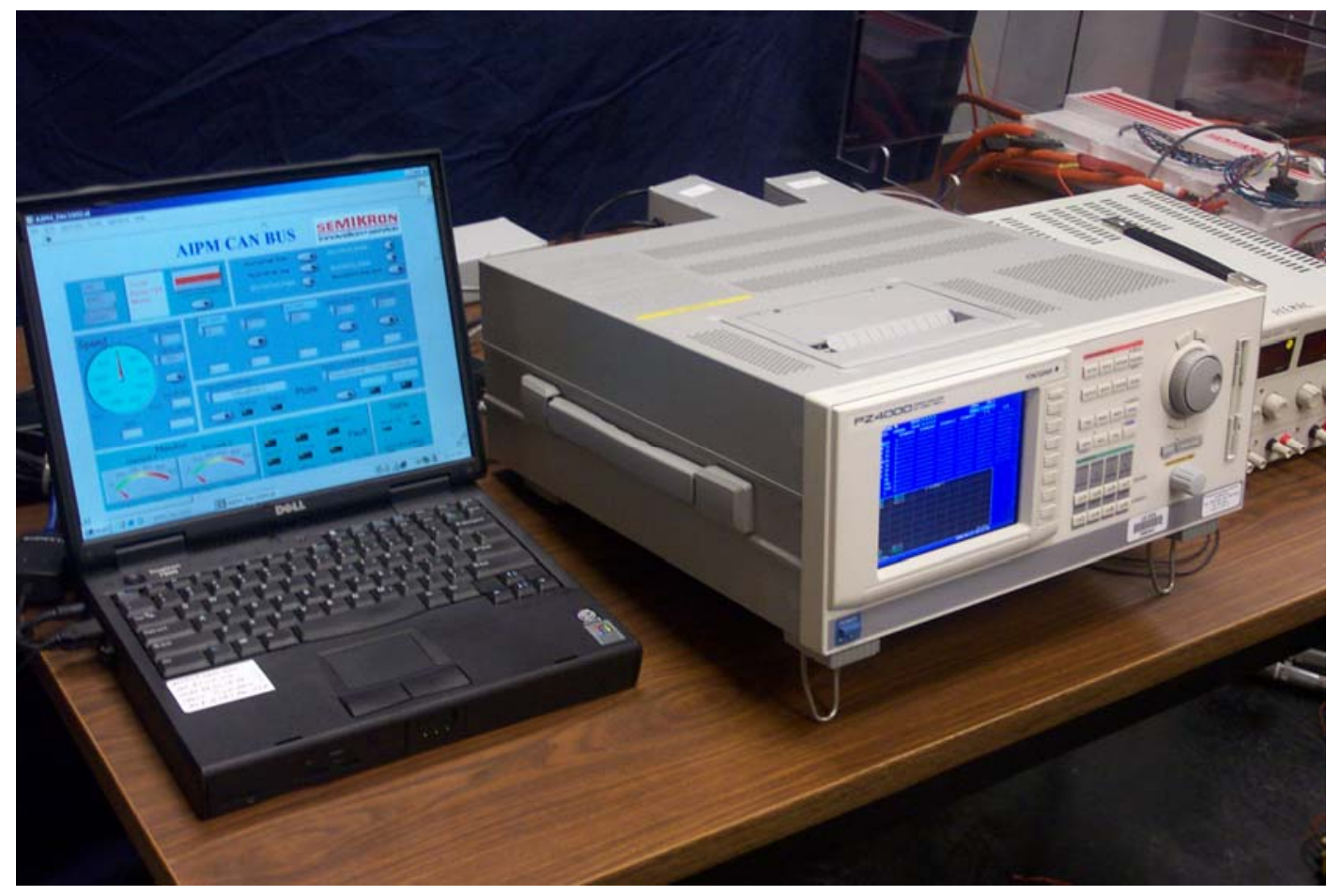

Fig. 2. Control computer, power meter, power supply, and Semikron unit.

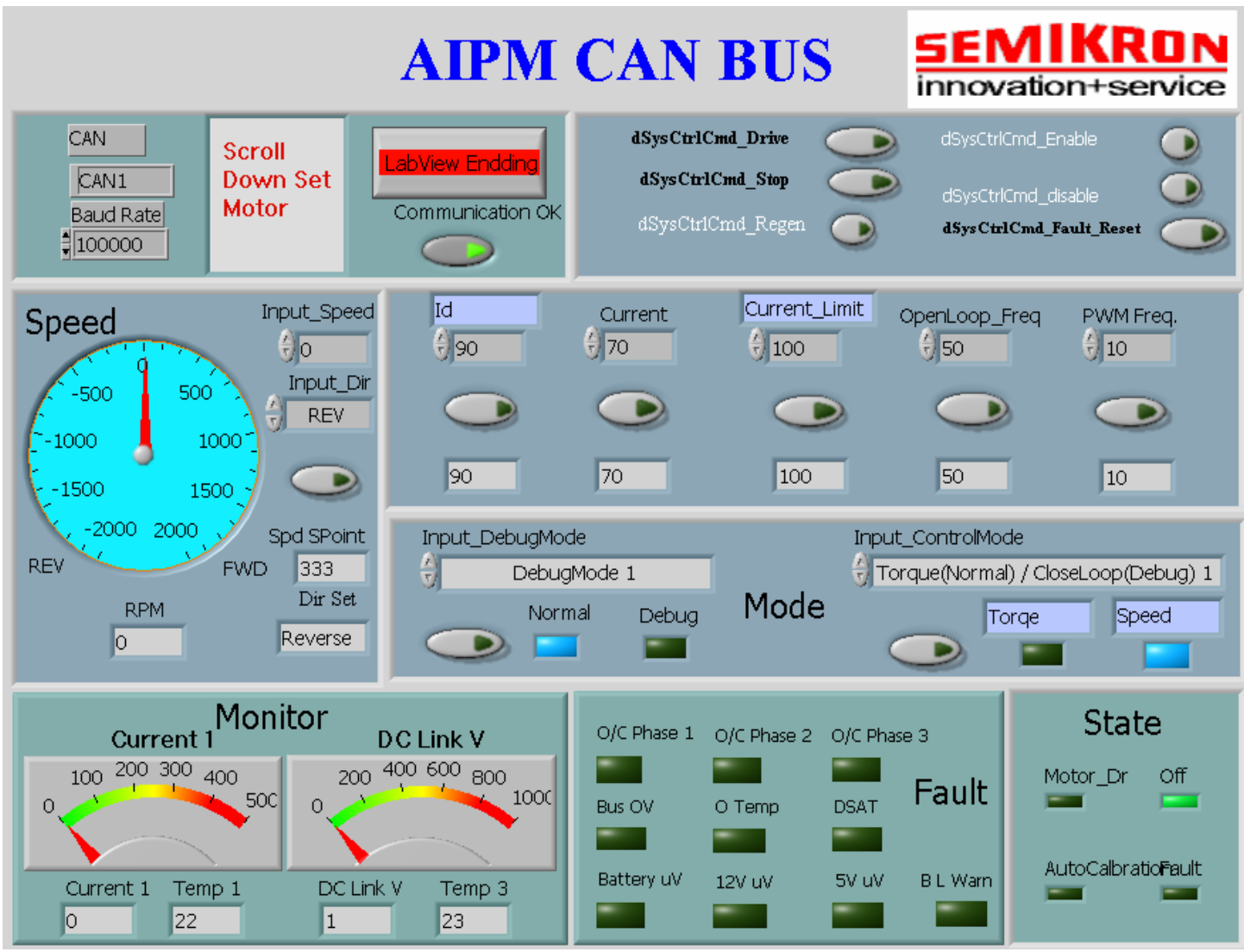

Fig. 3. CAN bus display. 


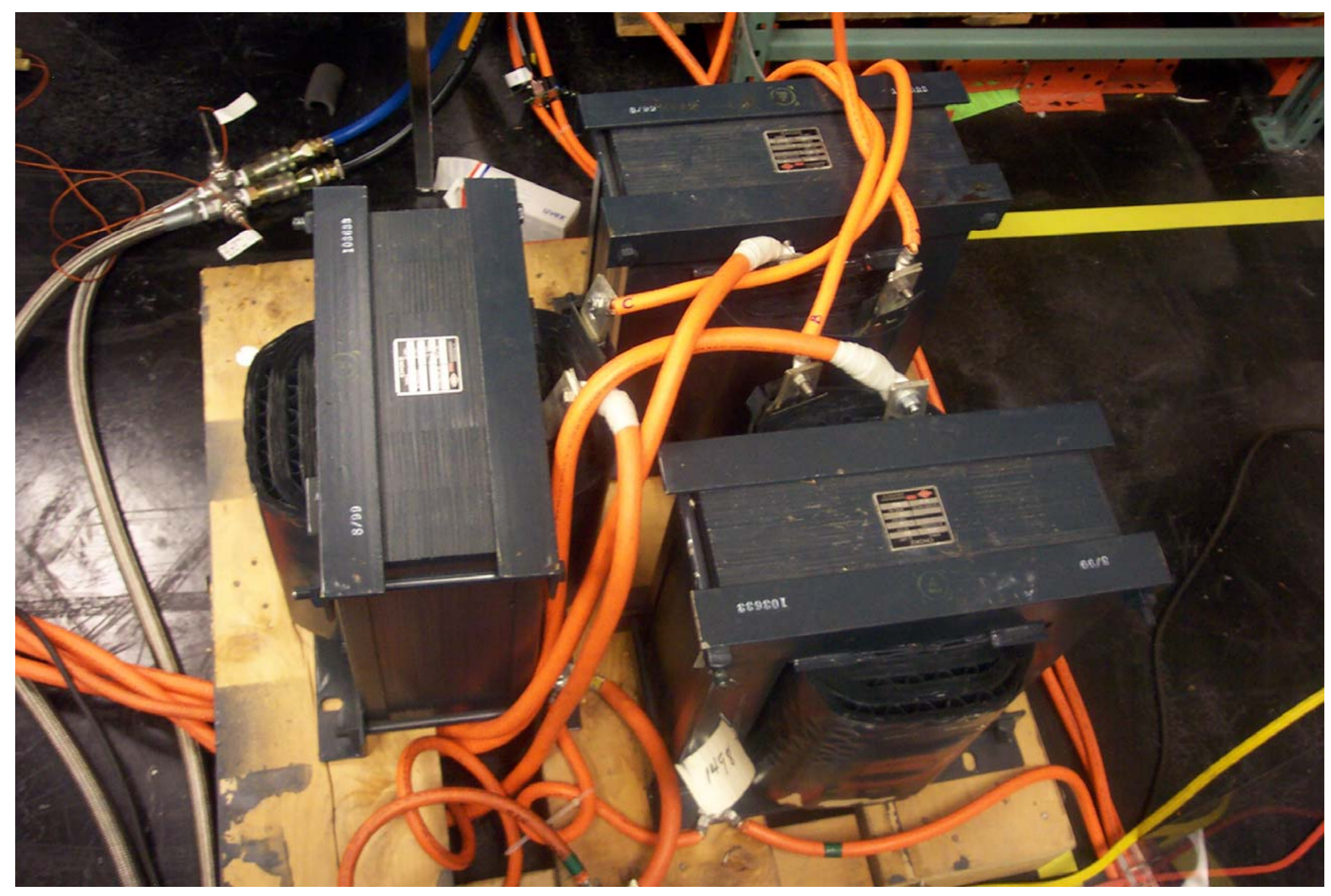

Fig. 4. Inductor load bank. 


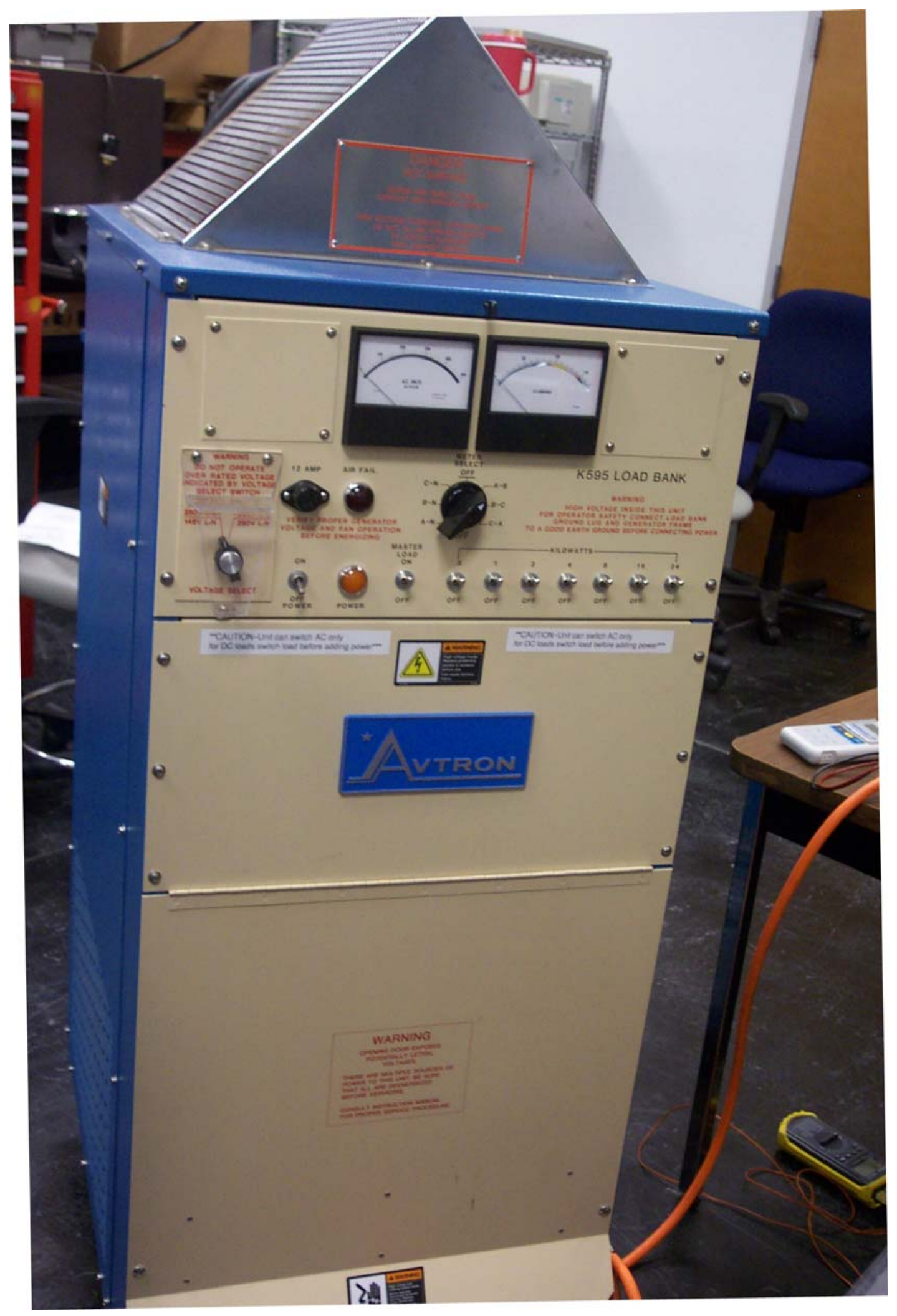

Fig. 5. Resistor load bank. 


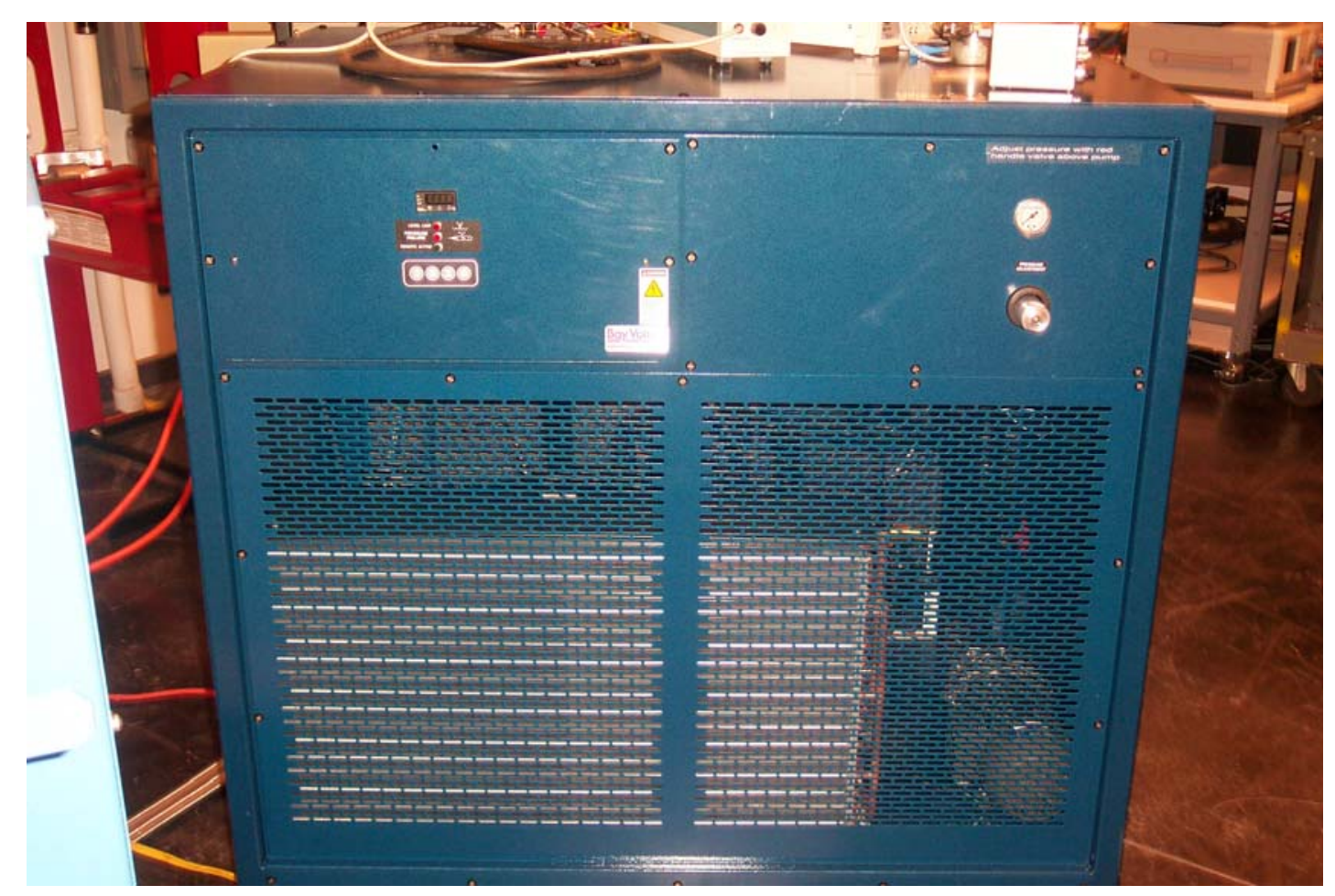

Fig. 6. Coolant temperature controller.

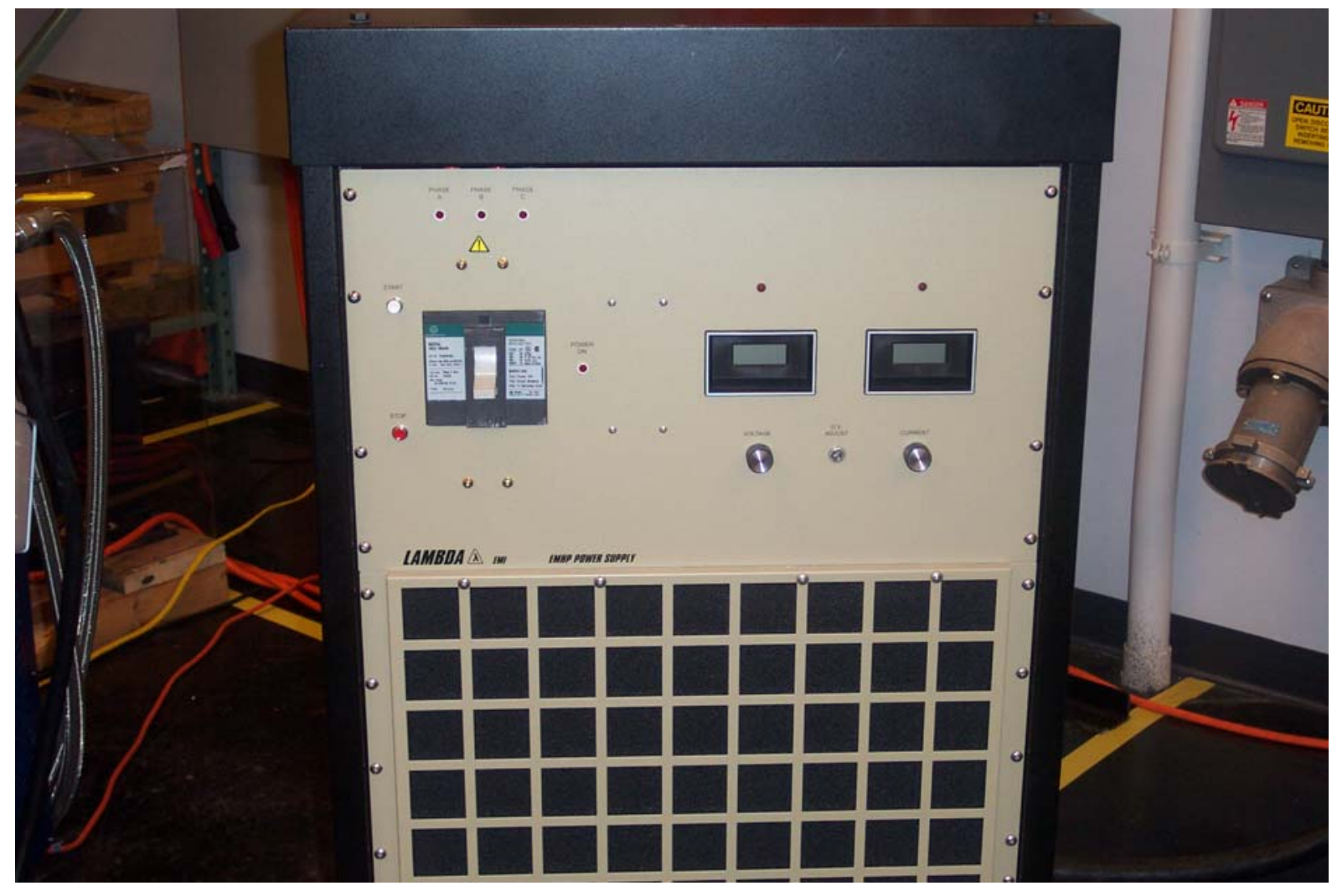

Fig. 7. DC power supply. 
Table 1 lists the test results when the inverter was operated at $50 \mathrm{~Hz}$ at six different power levels with a 200 Vdc link for short duration testing. The unit was operated at each test point for about one minute with $20^{\circ} \mathrm{C}$ coolant at a flow rate of $2.5 \mathrm{gpm}$. The average efficiency for the six data points is 0.966 , and the efficiency increased with increased power levels.

Table 1. Short duration testing of Semikron inverter with 200 Vdc link

\begin{tabular}{|c|c|c|c|c|c|c|c|c|c|}
\hline $\begin{array}{c}\text { dc link } \\
(\mathbf{V d c})\end{array}$ & $\begin{array}{c}\text { Freq } \\
(\mathbf{H z})\end{array}$ & $\begin{array}{c}\text { Idc } \\
(\mathbf{A})\end{array}$ & $\begin{array}{c}\text { Vac } \\
\left(\mathbf{V}_{\mathbf{L L}}\right)\end{array}$ & $\begin{array}{c}\text { lac } \\
\left(\mathbf{A}_{\mathbf{r m s}}\right)\end{array}$ & $\begin{array}{c}\text { Pin } \\
(\mathbf{k W})\end{array}$ & $\begin{array}{c}\text { Pout } \\
(\mathbf{k W})\end{array}$ & Effic. & $\begin{array}{c}\text { Cool. } \\
\left({ }^{\circ} \mathbf{C}\right)\end{array}$ & $\begin{array}{c}\text { Flow } \\
(\mathbf{g p m})\end{array}$ \\
\hline 200 & 50 & 7.5 & 87.5 & 24.9 & 1.51 & 1.43 & 0.947 & 20 & 2.5 \\
\hline 200 & 50 & 16.5 & 106.3 & 34.0 & 3.3 & 3.15 & 0.955 & 20 & 2.5 \\
\hline 200 & 50 & 28.1 & 123.1 & 43.3 & 5.71 & 5.54 & 0.970 & 20 & 2.5 \\
\hline 200 & 50 & 43.3 & 137.0 & 53.6 & 8.79 & 8.56 & 0.974 & 20 & 2.5 \\
\hline 200 & 50 & 61.5 & 149.4 & 64.5 & 12.46 & 12.14 & 0.974 & 20 & 2.5 \\
\hline 200 & 50 & 74.9 & 156.8 & 70.8 & 15.13 & 14.8 & 0.978 & 20 & 2.5 \\
\hline
\end{tabular}

Table 2 displays the test results when the inverter was operated with a 250 Vdc link for short duration testing with $20^{\circ} \mathrm{C}$ coolant with a 2.5 gpm flow. The unit had an average efficiency of 0.962 when operated with an output frequency of $10 \mathrm{~Hz}$ at seven different power levels. The inverter had an average efficiency of 0.976 when operated at five different output frequencies (i.e., 10, 20, 30, 50, and $60 \mathrm{~Hz}$ ) with a requested dc link current of $80 \mathrm{~A}$. The average efficiency during the load testing with a 250 Vdc link was 0.968.

Table 2. Short duration testing of Semikron inverter with 250 Vdc link

\begin{tabular}{|c|c|c|c|c|c|c|c|c|c|}
\hline $\begin{array}{c}\text { dc link } \\
(\mathbf{V d c})\end{array}$ & $\begin{array}{c}\text { Freq } \\
(\mathbf{H z})\end{array}$ & $\begin{array}{c}\text { Idc } \\
(\mathbf{A})\end{array}$ & $\begin{array}{c}\text { Vac } \\
\left(\mathbf{V}_{\mathbf{L L}}\right)\end{array}$ & $\begin{array}{c}\text { lac } \\
\left(\mathbf{A}_{\mathbf{r m s}}\right)\end{array}$ & $\begin{array}{c}\text { Pin } \\
(\mathbf{k W})\end{array}$ & $\begin{array}{c}\text { Pout } \\
(\mathbf{k W})\end{array}$ & Effic. & $\begin{array}{c}\text { Cool. } \\
\left({ }^{\circ} \mathbf{C}\right)\end{array}$ & $\begin{array}{c}\text { Flow } \\
(\mathbf{g p m})\end{array}$ \\
\hline 250 & 10 & 6.09 & 94.18 & 22.7 & 1.53 & 1.44 & 0.941 & 20 & 2.5 \\
\hline 250 & 10 & 13.19 & 114 & 33.7 & 3.3 & 3.13 & 0.948 & 20 & 2.5 \\
\hline 250 & 10 & 22.99 & 131.3 & 44.4 & 5.75 & 5.54 & 0.963 & 20 & 2.5 \\
\hline 250 & 10 & 35.19 & 146 & 54.2 & 8.79 & 8.5 & 0.967 & 20 & 2.5 \\
\hline 250 & 10 & 50.32 & 159.4 & 64.0 & 12.56 & 12.21 & 0.972 & 20 & 2.5 \\
\hline 250 & 10 & 67.62 & 171.7 & 74.0 & 16.88 & 16.45 & 0.975 & 20 & 2.5 \\
\hline 250 & 10 & 89.51 & 183.6 & 84.8 & 22.35 & 21.61 & 0.967 & 20 & 2.5 \\
\hline 250 & 20 & 89.99 & 184.9 & 85.5 & 22.47 & 21.84 & 0.972 & 20 & 2.5 \\
\hline 250 & 30 & 90.7 & 107.5 & 86.4 & 22.66 & 22.28 & 0.983 & 20 & 2.5 \\
\hline 250 & 50 & 87.08 & 190.4 & 84.7 & 21.71 & 21.21 & 0.977 & 20 & 2.5 \\
\hline 250 & 60 & 86.56 & 194.6 & 84.7 & 21.67 & 21.26 & 0.981 & 20 & 2.5 \\
\hline
\end{tabular}

Table 3 shows the test results when the unit was operated with a 400 and $450 \mathrm{Vdc}$ link for short duration testing. With a $400 \mathrm{Vdc}$ link, the unit was operated with an output frequency of 10 and $50 \mathrm{~Hz}$ with the same requested output current. The unit had a higher efficiency (0.986) when operated at $50 \mathrm{~Hz}$. The unit was tested with a $450 \mathrm{Vdc}$ link with an output frequency of 10, 50, and $70 \mathrm{~Hz}$ and the same requested output current. The inverter's efficiency exceeded the efficiency goal (i.e., 0.97) at 50 and $70 \mathrm{~Hz}$, but was below specification at $10 \mathrm{~Hz}(0.939)$. 
Table 3. Short duration testing of Semikron inverter with 400 and 450 Vdc link

\begin{tabular}{|r|r|r|r|r|r|r|r|r|c|}
\hline $\begin{array}{c}\text { dc link } \\
(\mathbf{V d c})\end{array}$ & $\begin{array}{c}\text { Freq } \\
(\mathbf{H z})\end{array}$ & $\begin{array}{c}\text { Idc } \\
(\mathbf{A})\end{array}$ & $\begin{array}{c}\text { Vac } \\
\left(\mathbf{V}_{\mathbf{L L}}\right)\end{array}$ & $\begin{array}{c}\text { lac } \\
\left(\mathbf{A}_{\mathbf{r m s}}\right)\end{array}$ & $\begin{array}{c}\text { Pin } \\
(\mathbf{k W})\end{array}$ & $\begin{array}{c}\text { Pout } \\
(\mathbf{k W})\end{array}$ & Effic. & $\begin{array}{c}\text { Cool. } \\
\left({ }^{\circ} \mathbf{C}\right)\end{array}$ & $\begin{array}{c}\text { Flow } \\
(\mathbf{g p m})\end{array}$ \\
\hline 400 & 10 & 35.6 & 294.7 & 37.7 & 14.22 & 13.95 & 0.981 & 20 & 2.5 \\
\hline 400 & 50 & 35.8 & 295.9 & 36.7 & 14.3 & 14.1 & 0.986 & 20 & 2.5 \\
\hline \multicolumn{7}{|c|}{} \\
\hline 450 & 10 & 40.5 & 331.6 & 40.5 & 18.34 & 17.22 & 0.939 & 20 & 2.5 \\
\hline 450 & 50 & 40.9 & 335.4 & 41.4 & 18.53 & 18.09 & 0.976 & 20 & 2.5 \\
\hline 450 & 70 & 45.5 & 337.1 & 42.5 & 18.66 & 18.36 & 0.984 & 20 & 2.5 \\
\hline
\end{tabular}

Table 4 displays the results when the unit was operated with a $325 \mathrm{Vdc}$ link for short duration testing with $70^{\circ} \mathrm{C}$ coolant and a flow rate of $2.5 \mathrm{gpm}$. The unit was operated at output frequencies of $10,20,50,75$, and $100 \mathrm{~Hz}$ with the same requested dc link current of 20,40,60, 80, and 100 A during the test. The Semikron inverter demonstrated efficiencies near or above the target efficiency (i.e., 0.97) when operated at a reasonable load. In general, the higher efficiencies were demonstrated when the unit was operated with an output frequency of $20 \mathrm{~Hz}$. Figure 10 plots efficiency vs. output power for the inverter based on the test results in Table 4.

The inverter was tested at continuous output power levels (i.e, $30 \mathrm{~kW}$ ) for 60 minutes with $70^{\circ} \mathrm{C}$ coolant with a flow rate of $2.5 \mathrm{gpm}$. Table 5 displays test data from the continuous power test. Figure 8 shows the test data from the power meter and the current waveforms for the inverter. The inverter operated with an efficiency of 0.972 at the end of the 60 minute test. Phase A, phase $\mathrm{B}$, and the dc link currents are displayed in the plot of Fig. 8. Note that the two-wattmeter method was used to measure the inverter's output per Blondel's theorem. Element 1 is measuring the input, and elements 2 and 3 are measuring the output of phases A and B. Element 4 is not being used in the test. Sum A and B are the summation of the dc input and the output of the inverter, respectively.

The inverter was operated at power levels greater than the continuous power level for short durations with $70^{\circ} \mathrm{C}$ coolant. The inverter demonstrated a peak power capability of $57.7 \mathrm{~kW}$ with an efficiency of 0.976 when operated with a dc link of $400 \mathrm{~V}$. The inverter produced 38.6 and $41.2 \mathrm{~kW}$ of output power when operated with a 325 and $335 \mathrm{Vdc}$ link. Table 6 summarizes the test results for short duration testing at power levels greater than $30 \mathrm{~kW}$. Figure 9 shows the test data from the power meter and the current waveforms at peak power. The inverter's input and output power was 59.17 and $57.74 \mathrm{~kW}$ for an efficiency of 0.976 . 
Table 4. Short duration testing of Semikron inverter with 325 Vdc link

\begin{tabular}{|c|c|c|c|c|c|c|c|c|c|}
\hline $\begin{array}{l}\text { dc link } \\
\text { (Vdc) }\end{array}$ & $\begin{array}{l}\text { Freq } \\
(\mathrm{Hz})\end{array}$ & $\begin{array}{l}\text { Idc } \\
\text { (A) }\end{array}$ & $\begin{array}{c}\text { Vac } \\
\left(V_{\mathrm{LL}}\right)\end{array}$ & $\begin{array}{c}\text { lac } \\
\left(A_{\text {rms }}\right)\end{array}$ & $\begin{array}{c}\text { Pin } \\
(k W)\end{array}$ & $\begin{array}{l}\text { Pout } \\
\text { (kW) }\end{array}$ & Effic. & $\begin{array}{c}\text { Cool. } \\
\left({ }^{\circ} \mathrm{C}\right)\end{array}$ & $\begin{array}{l}\text { Flow } \\
\text { (gpm) }\end{array}$ \\
\hline 325 & 10 & 5.4 & 108.2 & 27.0 & 1.8 & 1.6 & 0.892 & 70 & 2.5 \\
\hline 325 & 10 & 18.6 & 150.3 & 45.5 & 6.0 & 5.7 & 0.944 & 70 & 2.5 \\
\hline 325 & 10 & 40.1 & 182.4 & 65.2 & 13.0 & 12.4 & 0.957 & 70 & 2.5 \\
\hline 325 & 10 & 69.4 & 209.6 & 85.3 & 22.5 & 21.8 & 0.971 & 70 & 2.5 \\
\hline 325 & 10 & 104.4 & 232.6 & 104.0 & 33.7 & 32.8 & 0.973 & 70 & 2.5 \\
\hline 325 & 20 & 5.5 & 107.9 & 27.7 & 1.8 & 1.6 & 0.898 & 70 & 2.5 \\
\hline 325 & 20 & 18.7 & 150.3 & 45.9 & 6.0 & 5.8 & 0.957 & 70 & 2.5 \\
\hline 325 & 20 & 39.37 & 183.8 & 65.1 & 12.81 & 12.4 & 0.968 & 70 & 2.5 \\
\hline 325 & 20 & 69.7 & 210.1 & 85.7 & 22.4 & 22.0 & 0.983 & 70 & 2.5 \\
\hline 325 & 20 & 104.7 & 232.9 & 104.1 & 33.7 & 32.9 & 0.976 & 70 & 2.5 \\
\hline 325 & 50 & 5.1 & 110.9 & 26.9 & 1.6 & 1.5 & 0.909 & 70 & 2.5 \\
\hline 325 & 50 & 18.2 & 155.6 & 45.4 & 5.9 & 5.6 & 0.956 & 70 & 2.5 \\
\hline 325 & 50 & 39.8 & 188.9 & 65.3 & 12.8 & 12.3 & 0.964 & 70 & 2.5 \\
\hline 325 & 50 & 69.3 & 217.6 & 85.3 & 22.3 & 21.6 & 0.969 & 70 & 2.5 \\
\hline 325 & 50 & 105.9 & 242.2 & 105.5 & 34.0 & 33.2 & 0.976 & 70 & 2.5 \\
\hline 325 & 75 & 5.2 & 110.8 & 27.2 & 1.7 & 1.5 & 0.873 & 70 & 2.5 \\
\hline 325 & 75 & 18.3 & 163.3 & 45.5 & 5.9 & 5.6 & 0.959 & 70 & 2.5 \\
\hline 325 & 75 & 39.6 & 198.1 & 65.3 & 12.7 & 12.3 & 0.972 & 70 & 2.5 \\
\hline 325 & 75 & 68.9 & 228.5 & 85.4 & 22.1 & 21.4 & 0.970 & 70 & 2.5 \\
\hline 325 & 75 & 105.1 & 253.5 & 104.7 & 33.7 & 32.8 & 0.973 & 70 & 2.5 \\
\hline 325 & 100 & 5.0 & 122.5 & 26.4 & 1.6 & 1.4 & 0.894 & 70 & 2.5 \\
\hline 325 & 100 & 18.3 & 172.2 & 45.1 & 5.9 & 5.6 & 0.949 & 70 & 2.5 \\
\hline 325 & 100 & 39.4 & 209.8 & 64.8 & 12.6 & 12.3 & 0.969 & 70 & 2.5 \\
\hline 325 & 100 & 68.3 & 241.0 & 84.5 & 21.9 & 21.3 & 0.974 & 70 & 2.5 \\
\hline 325 & 100 & 84.2 & 257.2 & 94.0 & 27.4 & 26.7 & 0.974 & 70 & 2.5 \\
\hline
\end{tabular}




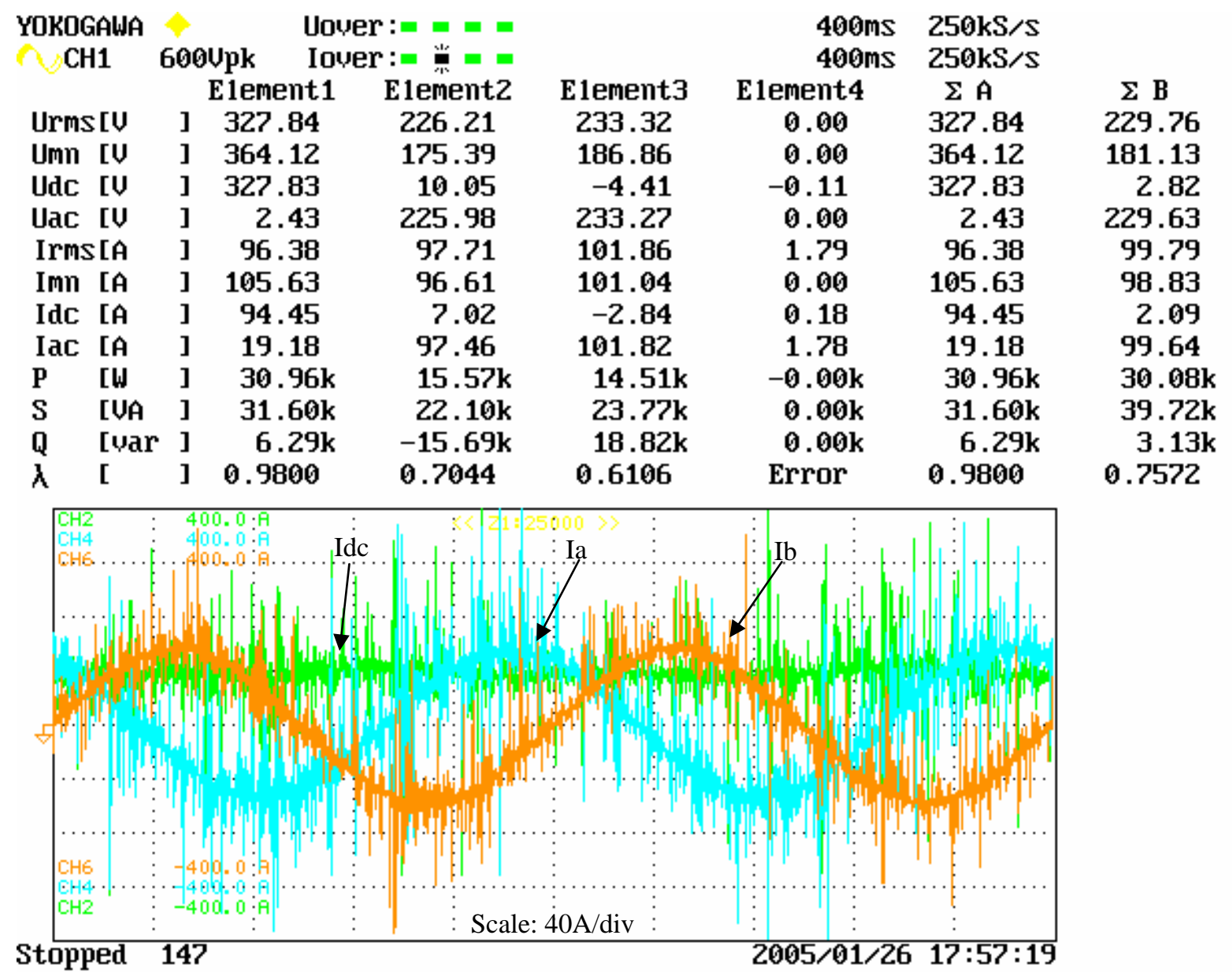

Fig. 8. Power meter readings and current waveforms at end on continuous power test.

Table 5. Continuous power testing of Semikron inverter with 325 Vdc link

\begin{tabular}{|r|r|c|c|c|c|c|c|c|c|c|}
\hline $\begin{array}{c}\text { dc link } \\
(\mathbf{V d c})\end{array}$ & $\begin{array}{c}\text { Freq } \\
(\mathbf{H z})\end{array}$ & $\begin{array}{c}\text { Idc } \\
(\mathbf{A})\end{array}$ & $\begin{array}{c}\text { Vac } \\
\left(\mathbf{V}_{\mathbf{L L}}\right)\end{array}$ & $\begin{array}{c}\text { lac } \\
\left(\mathbf{A}_{\mathbf{r m s}}\right)\end{array}$ & $\begin{array}{c}\text { Pin } \\
(\mathbf{k W})\end{array}$ & $\begin{array}{c}\text { Pout } \\
(\mathbf{k W})\end{array}$ & Effic. & $\begin{array}{c}\text { Cool. } \\
\left({ }^{\circ} \mathbf{C}\right)\end{array}$ & $\begin{array}{c}\text { Flow } \\
(\mathbf{g p m})\end{array}$ & $\begin{array}{c}\text { Time } \\
(\mathbf{m})\end{array}$ \\
\hline 325 & 20 & 94.99 & 229.6 & 99.4 & 30.9 & 30.1 & 0.975 & 70 & 2.5 & 5 \\
\hline 325 & 20 & 95.79 & 228.8 & 99.9 & 31.0 & 30.2 & 0.976 & 70 & 2.5 & 30 \\
\hline 325 & 20 & 94.47 & 229.8 & 99.5 & 31.0 & 30.0 & 0.967 & 70 & 2.5 & 45 \\
\hline 325 & 20 & 94.45 & 229.8 & 99.8 & 31.0 & 30.1 & 0.972 & 70 & 2.5 & 60 \\
\hline
\end{tabular}

Table 6. Testing of Semikron inverter at greater than continuous power levels

\begin{tabular}{|r|r|c|c|c|c|c|c|c|l|}
\hline $\begin{array}{c}\text { dc link } \\
(\mathbf{V d c})\end{array}$ & $\begin{array}{c}\text { Freq } \\
\mathbf{( H z )}\end{array}$ & $\begin{array}{c}\text { Idc } \\
(\mathbf{A})\end{array}$ & $\begin{array}{c}\text { Vac } \\
\left(\mathbf{V}_{\mathbf{L L}}\right)\end{array}$ & $\begin{array}{c}\text { lac } \\
\left(\mathbf{A}_{\mathbf{r m s}}\right)\end{array}$ & $\begin{array}{c}\text { Pin } \\
(\mathbf{k W})\end{array}$ & $\begin{array}{c}\text { Pout } \\
(\mathbf{k W})\end{array}$ & Effic. & $\begin{array}{c}\text { Cool. } \\
\left({ }^{\circ} \mathbf{C}\right)\end{array}$ & $\begin{array}{c}\text { Flow } \\
(\mathbf{g p m})\end{array}$ \\
\hline 325 & 20 & 118.7 & 242.1 & 111.2 & 38.6 & 37.7 & 0.977 & 70 & 2.5 \\
\hline 335 & 30 & 122.5 & 122.7 & 114.9 & 41.2 & 40.0 & 0.970 & 70 & 2.5 \\
\hline 400 & 20 & 147.1 & 299.6 & 137.5 & 59.2 & 57.7 & 0.976 & 70 & 2.5 \\
\hline
\end{tabular}




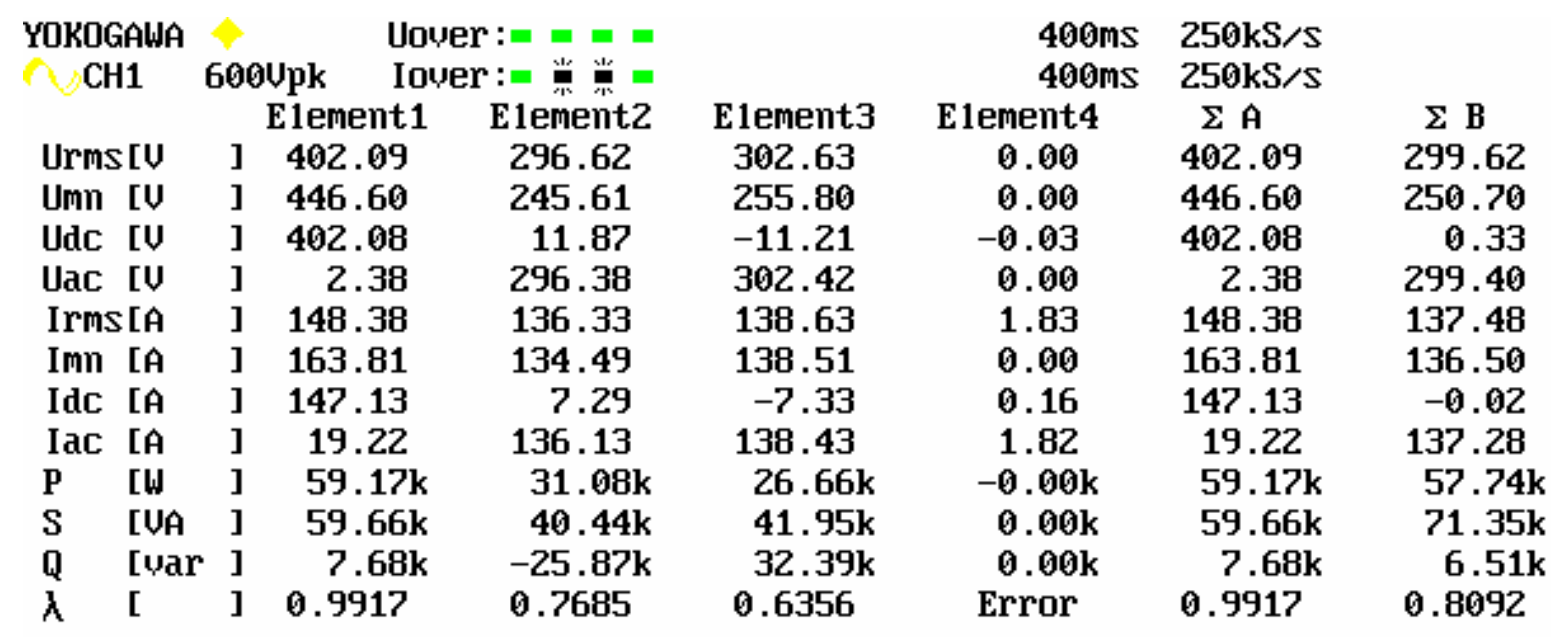

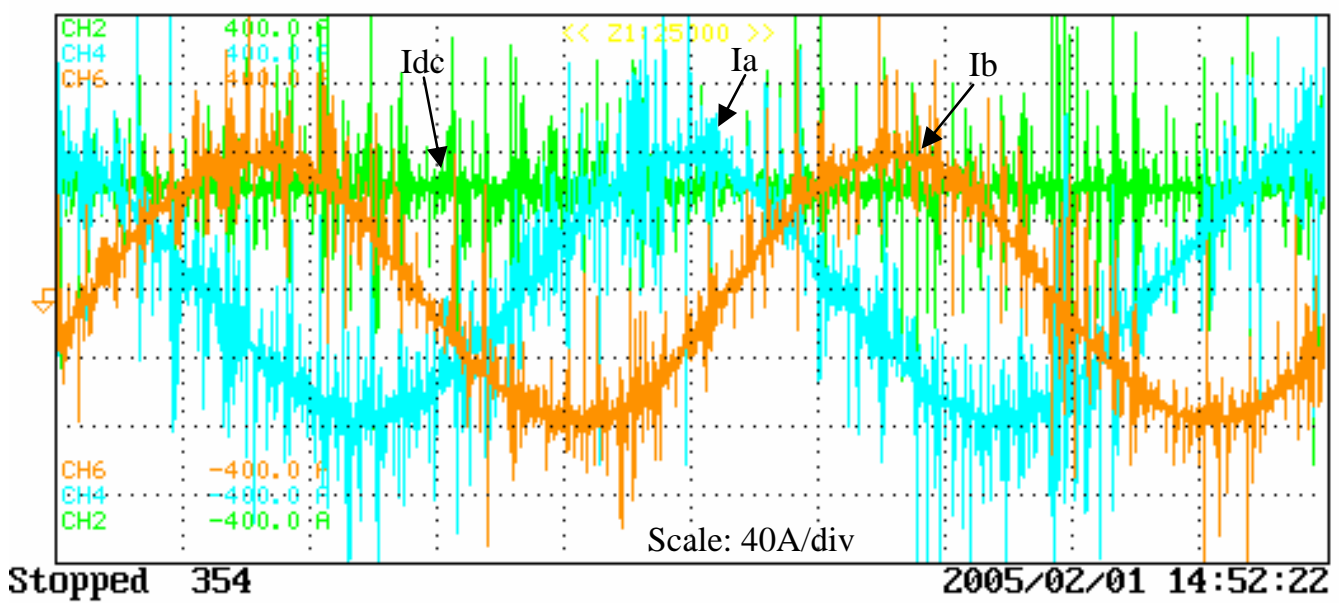

Fig. 9. Power meter readings and current waveforms at end on peak power test.

\section{Dynamometer Testing}

The inverter was tested driving a Solectria motor in the 100-hp dynamometer test cell at ORNL's NTRC. The Solectria motor is a four-pole induction motor with a base speed of $2500 \mathrm{rpm}$. Dynamometer testing was performed with a dc link voltage of $325 \mathrm{~V}$ with the inverter being supplied with $70^{\circ} \mathrm{C}$ coolant with a flow rate of $2.5 \mathrm{gpm}$. The inverter supplied electrical energy to drive the induction motor from 750 to 2500 rpm with a torque load of 100, 150, and $200 \mathrm{Nm}$.

Figure 11 plots the inverter efficiency vs. motor speed during the test. The highest efficiency (0.97) was obtained at $2500 \mathrm{rpm}$ with a load of $150 \mathrm{Nm}$. Table 7 presents the test data for the 100, 150, and $200 \mathrm{Nm}$ tests. The higher inverter efficiency was obtained near the base speed on the motor at the higher torque loads. The inverter meets the efficiency goal at a speed of 2500 rpm. Figure 12 plots torque vs. phase current with a family of curves at each speed. 


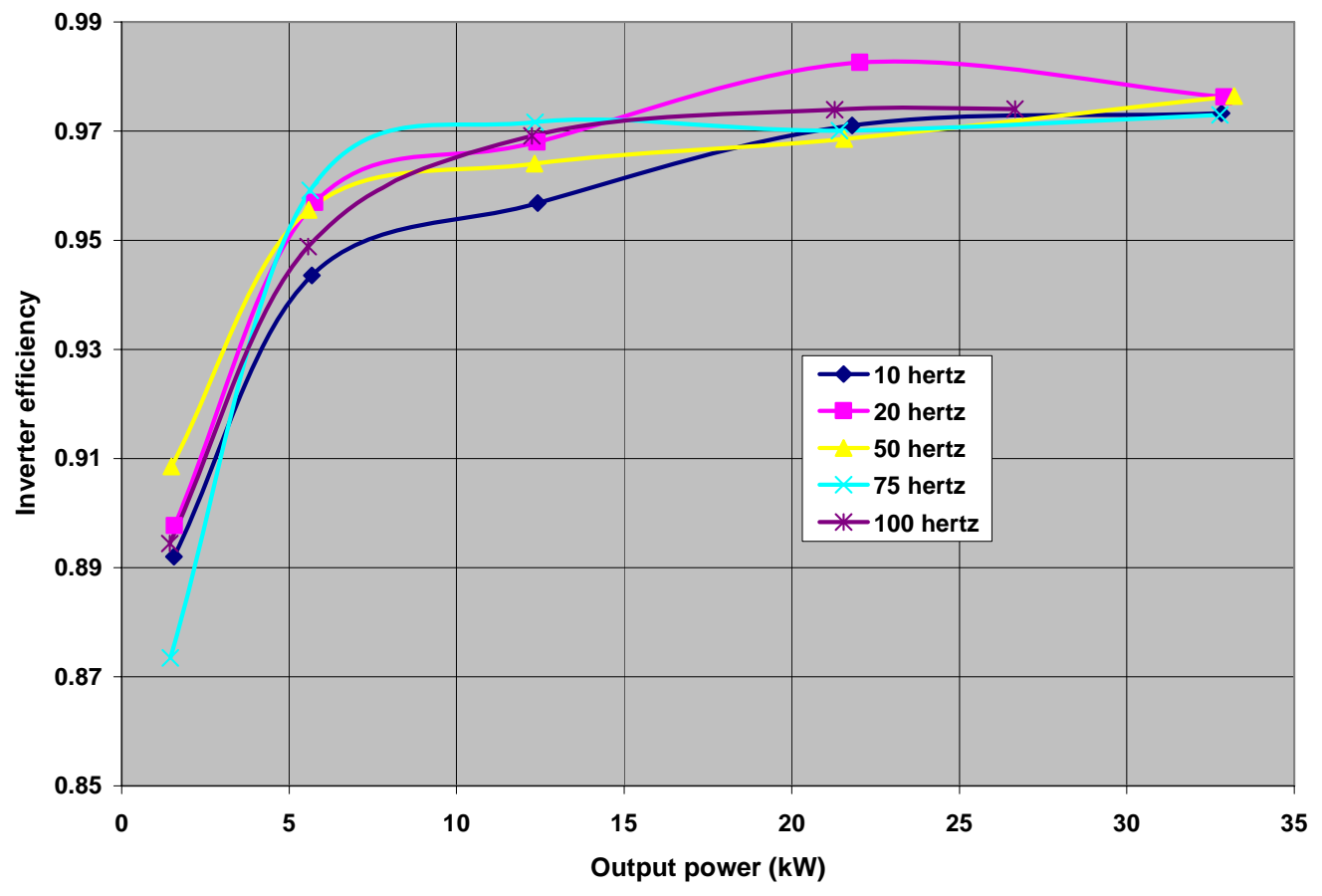

Fig. 10. Inverter efficiency vs. output power.

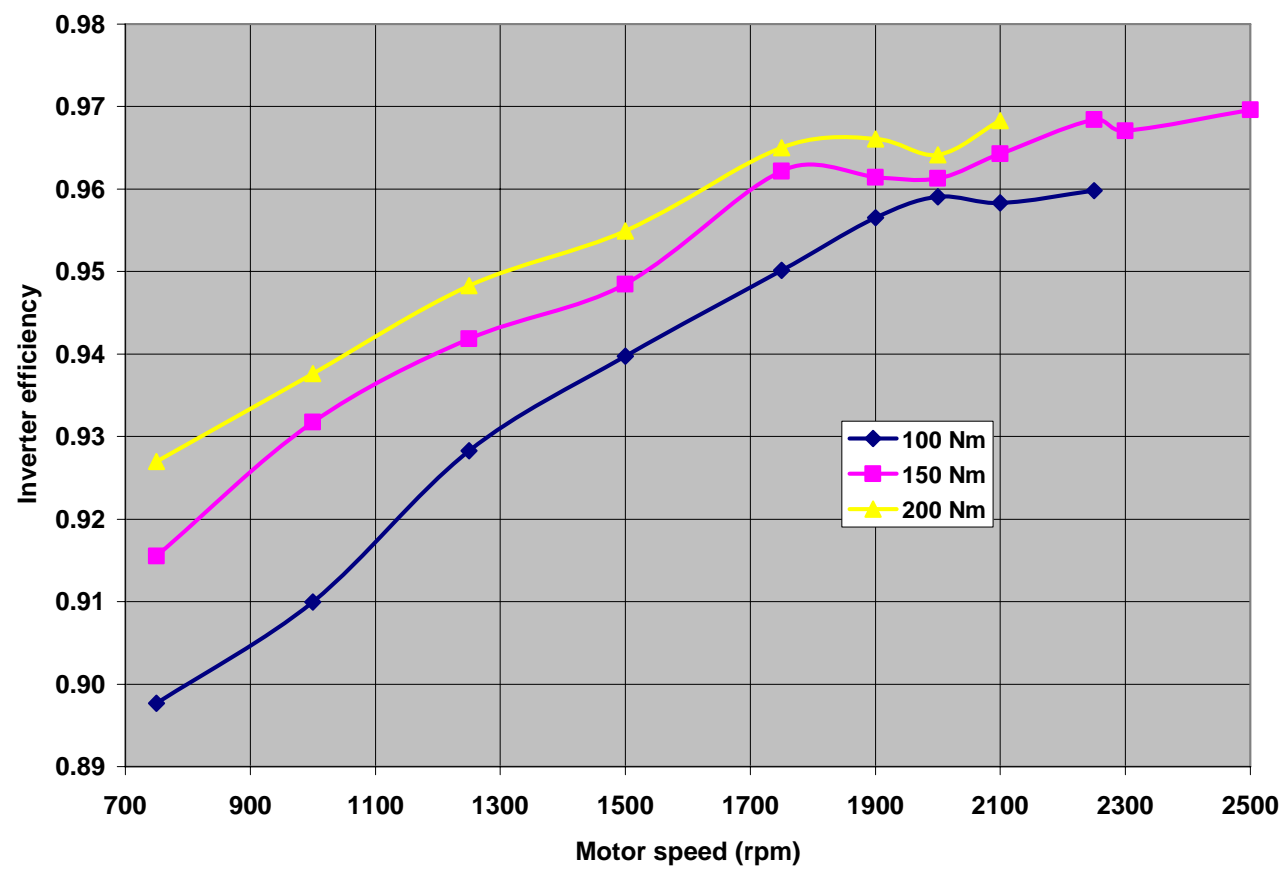

Fig. 11. Inverter efficiency vs. motor speed. 
Table 7. Dynamometer testing of Semikron inverter-speed vs. inverter efficiency

\begin{tabular}{|c|c|c|c|c|c|c|c|c|c|}
\hline $\begin{array}{c}\text { dc link } \\
\text { (Vdc) }\end{array}$ & $\begin{array}{c}\text { Speed } \\
(\mathrm{rpm})\end{array}$ & $\begin{array}{l}\text { Torq } \\
\text { (NM) }\end{array}$ & $\begin{array}{l}\text { Idc } \\
\text { (A) }\end{array}$ & $\begin{array}{c}\text { Vac } \\
\left(V_{\mathrm{LL}}\right)\end{array}$ & $\begin{array}{c}\text { lac } \\
\left(A_{\text {rms }}\right)\end{array}$ & $\begin{array}{l}\text { Pin } \\
(\mathrm{kW})\end{array}$ & $\begin{array}{l}\text { Pout } \\
\text { (kW) }\end{array}$ & $\begin{array}{c}\text { Mech } \\
(\mathrm{kW})\end{array}$ & $\begin{array}{l}\text { AIPM } \\
\text { Effic. }\end{array}$ \\
\hline 325 & 750 & 100 & 34.3 & 145.7 & 155.0 & 11.2 & 10.1 & 7.8 & 0.898 \\
\hline 325 & 1000 & 100 & 43.7 & 167.9 & 166.6 & 14.3 & 13.0 & 10.4 & 0.910 \\
\hline 325 & 1250 & 100 & 49.5 & 184.4 & 157.2 & 16.3 & 15.1 & 13.1 & 0.928 \\
\hline 325 & 1500 & 100 & 58.4 & 202.4 & 162.2 & 19.3 & 18.1 & 15.6 & 0.940 \\
\hline 325 & 1750 & 100 & 65.2 & 211.7 & 134.5 & 21.5 & 20.4 & 18.3 & 0.950 \\
\hline 325 & 1900 & 100 & 70.6 & 222.5 & 140.5 & 23.2 & 22.2 & 19.9 & 0.957 \\
\hline 325 & 2000 & 100 & 72.7 & 222.6 & 130.0 & 23.9 & 23.0 & 20.9 & 0.959 \\
\hline 325 & 2100 & 100 & 78.0 & 235.3 & 144.3 & 25.7 & 24.6 & 21.9 & 0.958 \\
\hline 325 & 2250 & 100 & 82.5 & 241.3 & 142.7 & 27.1 & 26.0 & 23.5 & 0.960 \\
\hline 325 & 750 & 150 & 195 & 1475 & 1780 & 162 & 149 & 118 & 0016 \\
\hline 325 & 1000 & 150 & 62.0 & 169.8 & 189.1 & 20.7 & 19.2 & 15.7 & 0.932 \\
\hline 325 & 1250 & 150 & 72.1 & 184.9 & 180.5 & 23.7 & 22.4 & 19.6 & 0.942 \\
\hline 325 & 1500 & 150 & 85.5 & 203.0 & 184.4 & 28.2 & 26.7 & 23.5 & 0.948 \\
\hline 325 & 1750 & 150 & 97.2 & 208.7 & 161.3 & 32.0 & 30.8 & 27.4 & 0.962 \\
\hline 325 & 1900 & 150 & 105.7 & 223.7 & 169.6 & 34.7 & 33.4 & 31.4 & 0.961 \\
\hline 325 & 2000 & 150 & 109.2 & 211.1 & 165.6 & 35.9 & 34.5 & 31.4 & 0.961 \\
\hline 325 & 2100 & 150 & 115.9 & 234.3 & 170.1 & 38.1 & 36.7 & 33.0 & 0.964 \\
\hline 325 & 2250 & 150 & 121.5 & 233.7 & 162.4 & 39.9 & 38.6 & 35.2 & 0.968 \\
\hline 325 & 2300 & 150 & 127.2 & 251.2 & 190.3 & 41.9 & 40.5 & 36.1 & 0.967 \\
\hline 325 & 2500 & 150 & 140.5 & 232.1 & 178.1 & 46.1 & 44.7 & 40.0 & 0.970 \\
\hline 325 & 50 & 200 & 2 & 3 & 2 & 218 & 20 & 157 & 927 \\
\hline 325 & 1000 & 200 & 83.7 & 170.8 & 215.8 & 27.4 & 25.7 & 20.9 & 0.938 \\
\hline 325 & 1250 & 200 & 96.5 & 185.8 & 209.9 & 31.7 & 30.1 & 26.1 & 0.948 \\
\hline 325 & 1500 & 200 & 114.0 & 204.0 & 215.6 & 37.5 & 35.8 & 31.4 & 0.955 \\
\hline 325 & 1750 & 200 & 132.2 & 212.9 & 204.1 & 43.4 & 41.9 & 36.7 & 0.965 \\
\hline 325 & 1900 & 200 & 141.9 & 221.9 & 205.0 & 46.6 & 45.0 & 39.8 & 0.966 \\
\hline 325 & 2000 & 200 & 147.8 & 217.2 & 210.2 & 48.5 & 46.8 & 42.0 & 0.964 \\
\hline 325 & 2100 & 200 & 155.9 & 234.0 & 206.0 & 51.1 & 49.5 & 43.9 & 0.968 \\
\hline
\end{tabular}

The inverter was tested at continuous power ( $30 \mathrm{~kW}$ ) by driving the motor from 1000 to 2400 rpm. Figure 13 shows the tests results at seven different motor speeds with the inverter supplying $30 \mathrm{~kW}$ of electrical power. The inverter had an efficiency that ranged from 0.94 to 0.97 with an output power of $30 \mathrm{~kW}$.

Figure 14 shows the power meter readings and current waveforms during the continuous power test on the dynamometer. The inverter was operating with an efficiency of 0.943 based on an input power of $32.17 \mathrm{~kW}$ and an output power of $30.35 \mathrm{~kW}$. Figures 15 and 16 shows a view of the dynamometer test cell from the control room with load motor and dynamometer. 


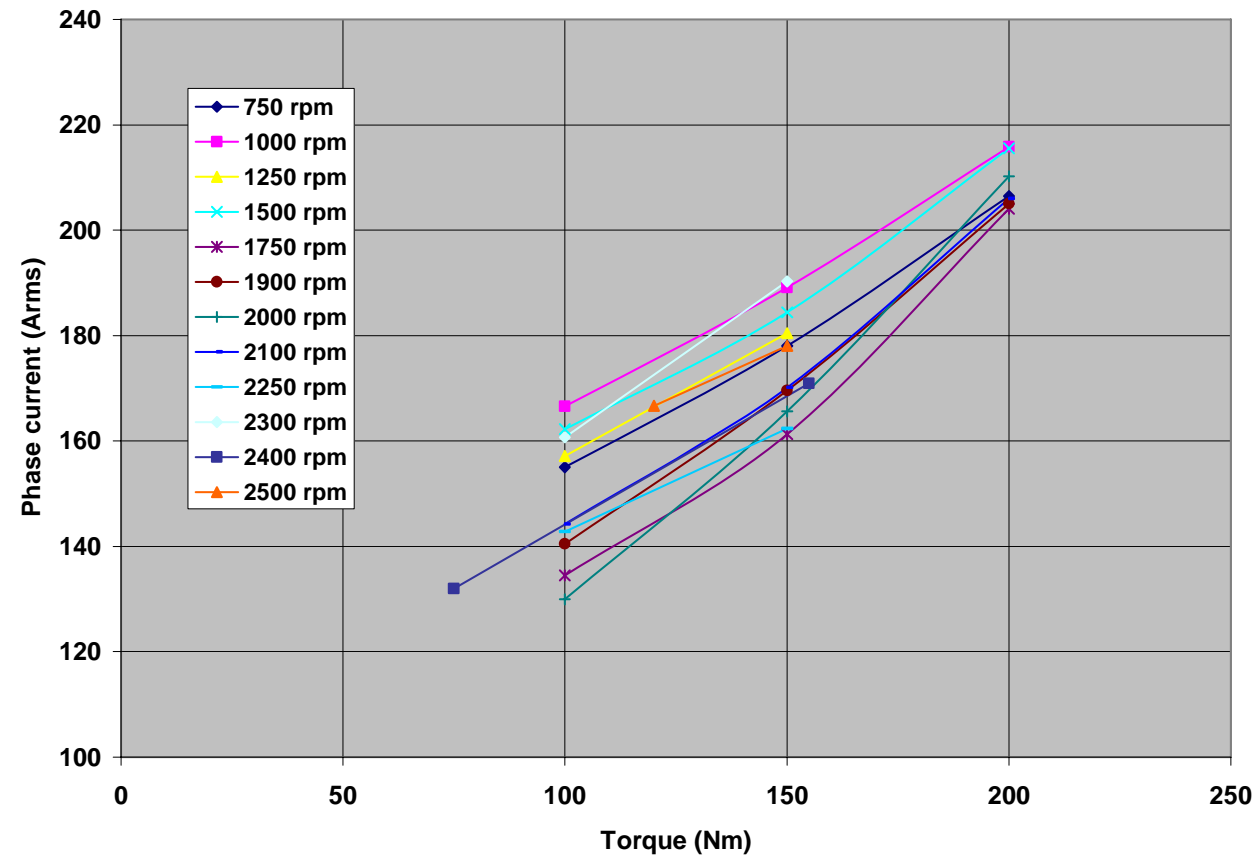

Fig. 12. Semikron inverter phase current vs. torque.

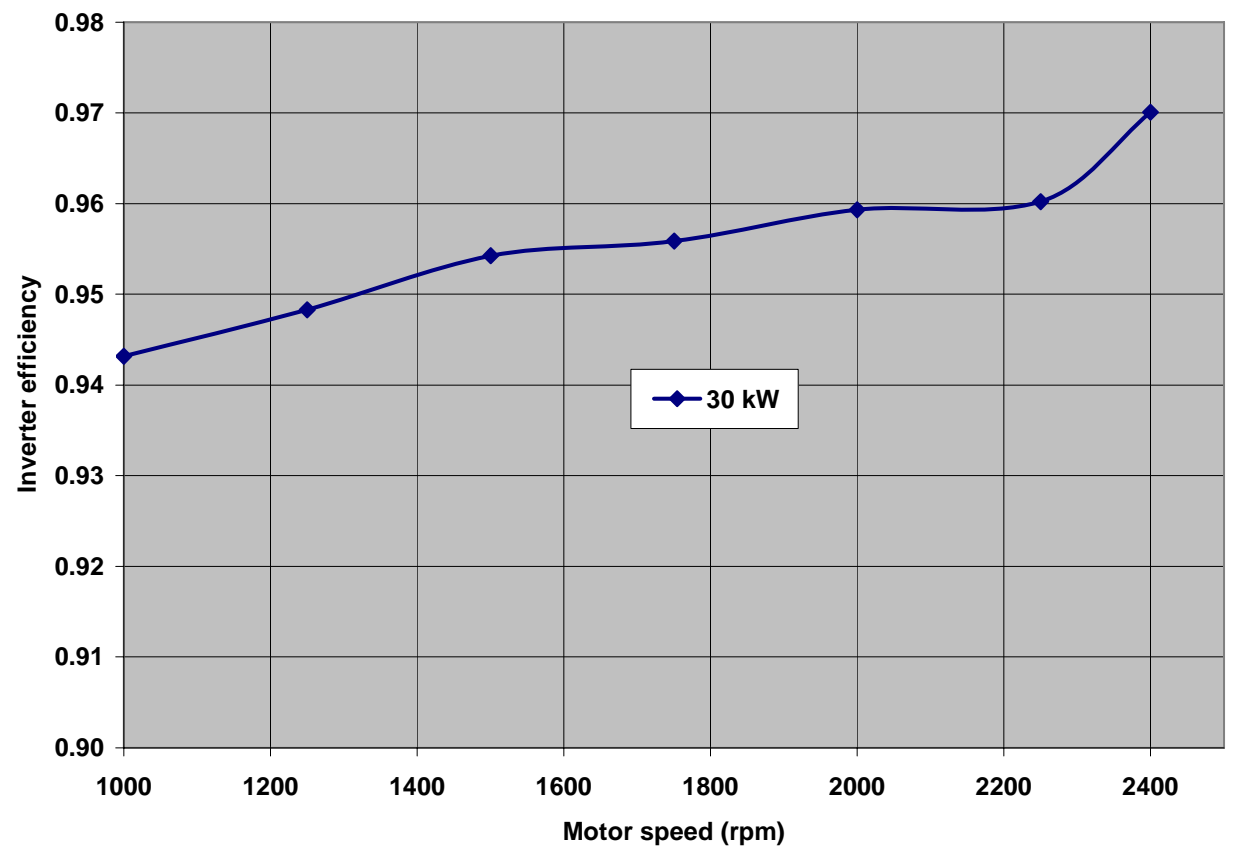

Fig. 13. Semikron inverter efficiency vs. speed at continuous power. 


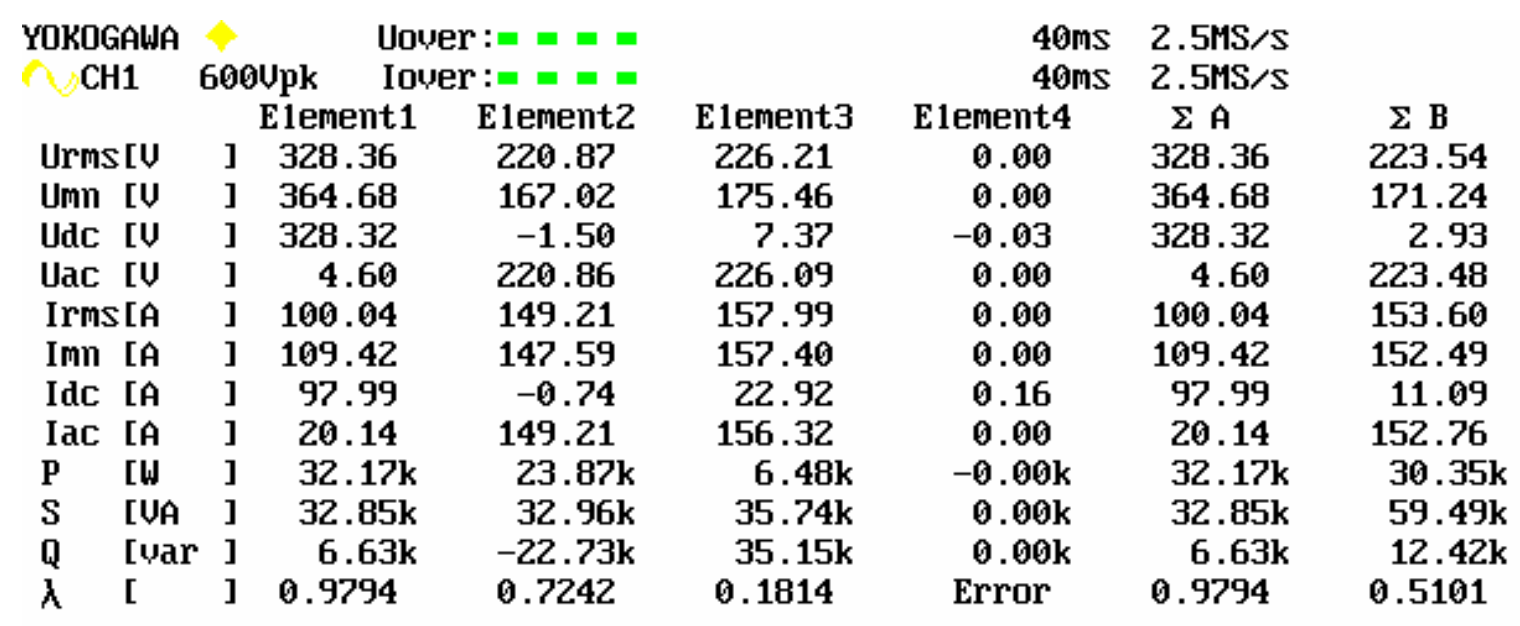

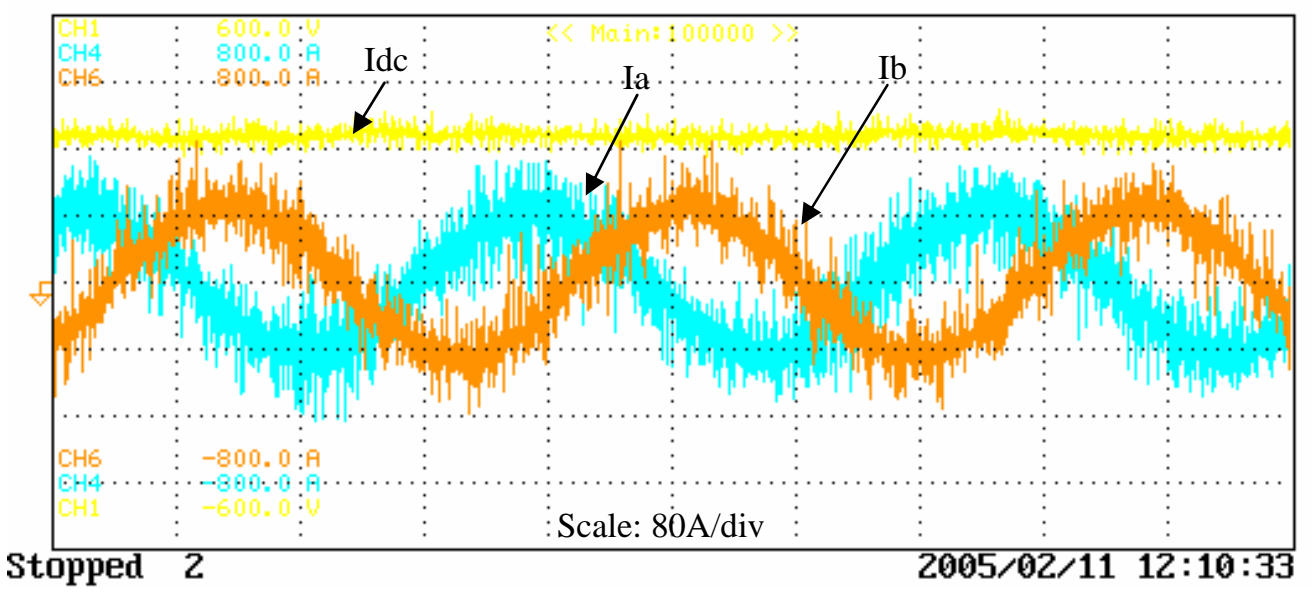

Fig. 14. Power meter readings and current waveforms during continuous power test on dyne.

\section{CONCLUSIONS}

The Semikron AIPM inverter demonstrated the ability to operate at the continuous and peak power levels when supplied with $70^{\circ} \mathrm{C}$ coolant at $2.5 \mathrm{gpm}$ for induction load tests. The inverter operated at continuous power levels for 60 minutes during the induction load tests with an average efficiency of 0.972 .

During dynamometer testing the inverter had efficiencies that ranged from 0.94 to 0.97 when operated at continuous power levels. The controller for the inverter had a maximum speed setting of $2500 \mathrm{rpm}$ that prevented driving the motor to higher speeds. The unit as delivered had a peak specific power density of 7.1 peak $\mathrm{kW} / \mathrm{kg}$ exceeding the goal of $5 \mathrm{~kW} / \mathrm{kg}$. The unit had a volumetric peak power density of 8 peak $\mathrm{kW} / \mathrm{l}$ failing to meet the goal of $12 \mathrm{~kW} / \mathrm{l}$. Table 8 summarizes the details used in this calculation. 
Table 8. Specific power density summary

\begin{tabular}{|l|c|c|}
\hline Characteristic & Semikron measurement & FreedomCAR goal \\
\hline Weight (kg) & 7.7 & NA \\
\hline Volume (l) & 6.9 & NA \\
\hline Peak power (kW) & 55 & 55 \\
\hline $\begin{array}{l}\text { Peak specific power density } \\
\text { (Peak kW/kg) }\end{array}$ & 7.1 & 5 \\
\hline $\begin{array}{l}\text { Peak volumetric power density } \\
\text { (Peak kW/l) }\end{array}$ & 8 & 12 \\
\hline
\end{tabular}




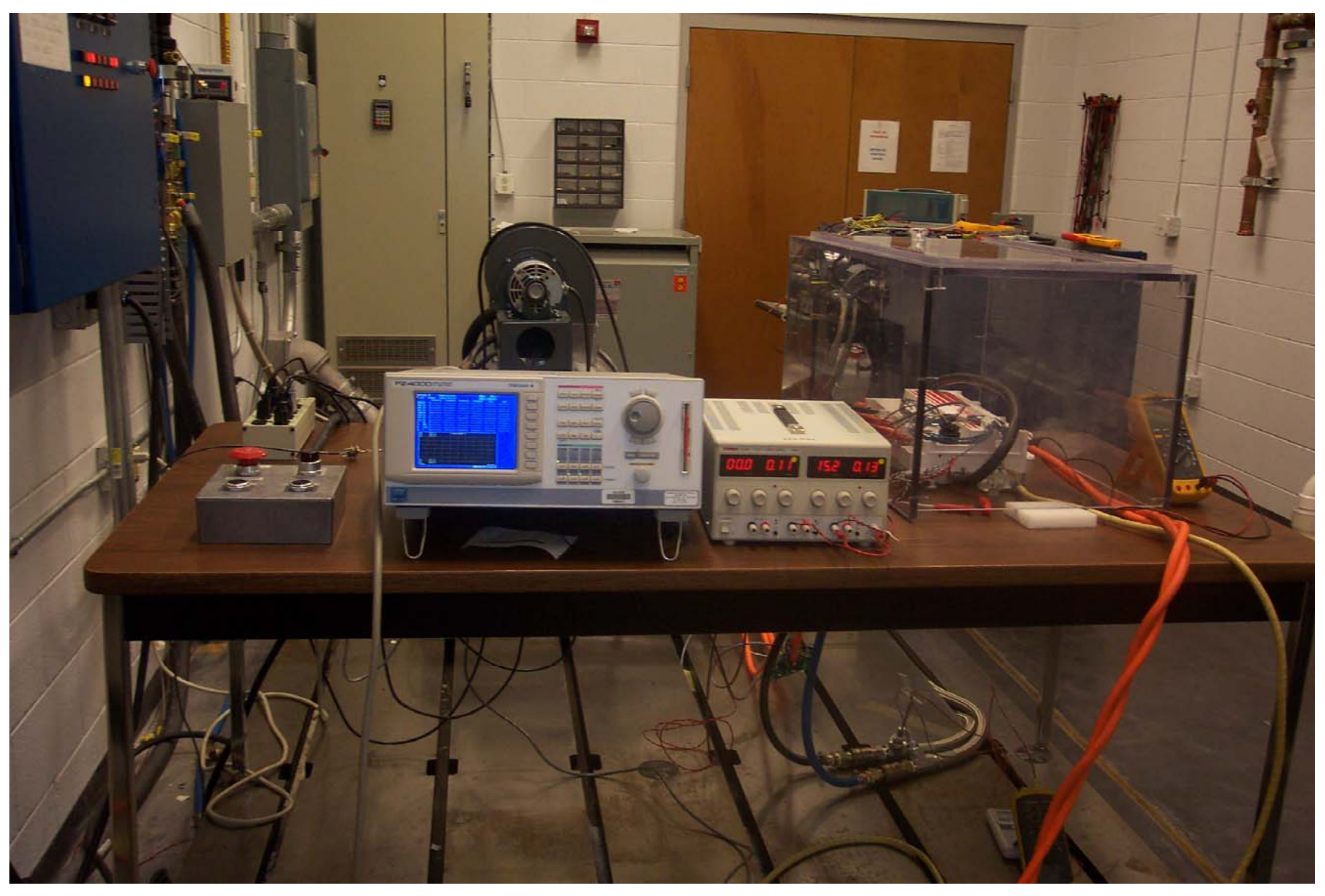

Fig. 15. View of dynamometer test cell from control room. 


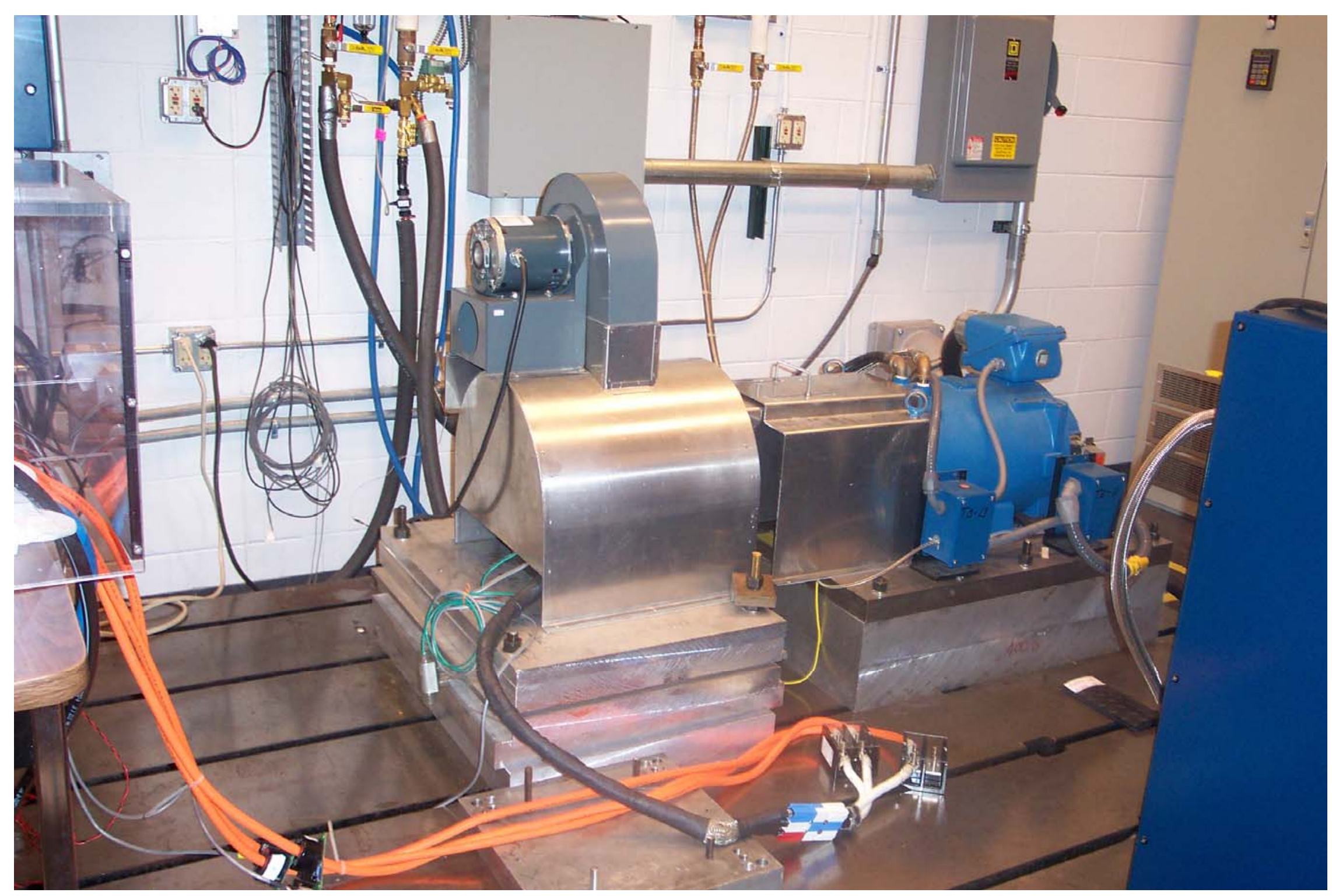

Fig. 16. Load motor and 100-hp dynamometer. 


\title{
APPENDIX A:
}

\section{AUTOMOTIVE INTEGRATED POWER MODULE (AIPM) TEST PLAN}

\author{
Revision 0
}

January 2005

\section{A.1 INTRODUCTION}

This document describes the tests to be performed as part of the overall evaluation of the Automotive Integrated Power Module (AIPM) hardware to be delivered by the contractors to the Oak Ridge National Laboratory (ORNL). These evaluations are to be done on behalf of the Department of Energy (DOE) to ascertain whether the units meet the target specifications referenced in the contracts and to determine their overall performance capabilities. The tests described herein may or may not be fully implemented, depending on several parameters such as funding, whether the prototype is deemed capable of surviving the tests, etc. Additionally, tests beyond those described herein may be performed at the discretion of ORNL or DOE. It is important to recognize that AIPMs should be designed to the referenced specifications and not to simply pass the evaluation tests. AIPMs that are determined to be designed to pass the test parameters rather than to meet the intent of the specification are not acceptable.

The intent of this test plan is to acquire the required data to characterize the device under test (DUT). In many cases, it is planned to utilize data acquisition systems to acquire and store data so that key parameters, such as efficiency, voltage regulation, etc., can be determined for the DUT at various operational conditions.

Two basic test setups are used in this test plan, an inductive load and a dynamometer system setup. For inductive load testing, the ac (alternating current) output of the DUT is connected to a three-phase inductive load and the dc (direct current) input is connected to a voltage source capable of supplying the appropriate voltage and current levels for the DUT. Some inductive load tests are performed prior to dynamometer tests to detect problems early in the test sequence.

There are two primary modes of operation for the DUT when the dynamometer is used in the test plan. During motoring tests, the DUT is supplying power to the motor and a family of inverter efficiency curves can be determined at various speeds and torques. Section 3 contains a summary of what test-setup is utilized for each test.

The DUT will require cooling when it is operated during inductive load or dynamometer tests. Typically, nominal cooling parameters are required for the tests being performed (see AIPM specification). The inlet coolant temperature should be controlled to the upper limit $\left(70^{\circ} \mathrm{C}\right)$ when the performance of the unit is being compared to the AIPM specification. 


\section{A.2 INITIAL ELECTRICAL TEST (CHARACTERIZATION)}

\section{A.2.1 Receipt of DUT}

The DUT shall be examined to determine that damage has not occurred during shipping or handling, and that the configuration of the DUT agrees with the information supplied by the vendor. Measure and record the following information: weight and dimensions.

\section{A.2.2 Electrical Tests on Bench}

\section{A.2.2.1 Isolation impedance}

Perform the following safety check, prior to the start of electrical testing, to verify the unit was not damaged during shipping. Measure with a multi-meter the isolation impedance between terminals and case of DUT to verify no fault conditions. The isolation impedance terminal to case of the DUT should be $\geq 1 \mathrm{M} \Omega$.

\section{A.2.2.2 Inductive load test}

During the inductive load test, the ac outputs (of each phase) of the DUT will be connected to an inductive load in series with a matched resistor to provide $\mathrm{a} \geq 80 \%$ power factor for the output frequency of the DUT. The dc inputs for the DUT are connected to a voltage source capable of supplying the maximum rated operating voltage and current levels for the DUT. The inductor and resistor should be rated for the current and power required for the test. Record the power rating of the DUT and do not exceed the rating during the inductive load test.

\section{A.2.2.2.1 Minimal dc link voltage test with inductive load}

Apply minimal dc link voltage to the DUT and establish current flow at approximately 10 A. Check to confirm the current phases and dead times are correct prior to increasing the current. Increase dc link current in steps of 10 to $20 \mathrm{~A}$ without exceeding the power rating for the DUT; record the dc link voltage, dc link current, input power, output power, output frequency, and output currents and voltages. Operate the DUT at each current level for approximately one minute. Repeat step in third sentence of this paragraph (i.e., increase dc link current).

\section{A.2.2.2.2 Maximum dc link voltage test with inductive load}

Repeat step A.2.2.2.1 with maximum dc link voltage.

\section{A.2.2.2.3 Nominal voltage test with inductive load}

Operate the DUT at $10 \mathrm{~Hz}$ and repeat step A.2.2.2.1 with nominal dc link voltage. Increase the output frequency of the unit by 10 to $30 \mathrm{~Hz}$ and repeat step A.2.2.2.1. Operate the DUT at a total of three to six different output frequencies at nominal dc link voltage. 


\section{A.2.2.2.4 Continuous power test}

Confirm ability of unit to operate at continuous power levels for one hour with nominal rated dc link voltage. Record current waveforms and test data at the end of one hour of operation.

\section{A.2.2.2.5 Peak power test}

Confirm ability of unit to operate at peak power levels for 24 seconds with nominal rated de link voltage. Record current waveforms and test data at the end of the peak power test.

\section{A.2.3 Electrical Test on Dynamometer System}

Connect the DUT to the drive motor on the dynamometer system. Verify the test setup and that the data acquisition system is operational. Record the model, serial number, and parameters of the motor utilized in the test. The motor parameters should include horse-power or $\mathrm{kW}$, maximum rated speed and torque. Record the ambient temperature of the laboratory (dynamometer test cell) at the beginning and end of each dynamometer run. Do not exceed any parameter for the DUT or the test motor (i.e. maximum rated speed).

\section{A.2.3.1 Nominal battery voltage}

Verify the nominal battery voltage and the rated and maximum output currents (at the nominal voltage) for the DUT. Set the dc voltage input to the DUT at the nominal battery operating voltage and do not exceed the maximum limit of the output currents from the inverter. Drive the load motor from rest to the rated speed in increments of approximately $10 \%$ of the rated motor speed and apply increasing torque loads to the motor. Increase speed by $10 \%$ and repeat previous step until the target motor speed is obtained. Drive the motor to rest. Operate the coolant system for the DUT at nominal conditions during this test.

Record the following information at each speed increment: motor shaft speed (rpm), motor's torque load and mechanical power, input voltage and current to the inverter, and output voltages and currents from the inverter.

\section{A.3 TEST SETUP SUMMARY}

This test plan utilizes two basic test setups, testing with an inductive load and testing with the dynamometer system. The table below summarizes what setup is used for each test and in some tests the DUT is inactive.

\begin{tabular}{|c|l|c|c|c|}
\hline Test No. & Test description & $\begin{array}{c}\text { Inductive } \\
\text { Load }\end{array}$ & $\begin{array}{c}\text { Dynamometer } \\
\text { Test }\end{array}$ & Inactive \\
\hline A.2.2.1 & Isolation impedance & & & $\mathrm{x}$ \\
\hline A.2.2.2 & Inductive load & $\mathrm{x}$ & & \\
\hline A.2.3.1 & Nominal battery voltage & & $\mathrm{x}$ & \\
\hline
\end{tabular}




\section{APPENDIX B:}

\section{RECOMMENDED AIPM AND AEMD SPECIFICATION}

\begin{tabular}{|c|c|c|c|c|}
\hline Requirement & $\begin{array}{l}\text { AIPM } \\
\text { series }\end{array}$ & $\begin{array}{l}\text { AEMD } \\
\text { series }\end{array}$ & $\begin{array}{l}\text { AIPM } \\
\text { parallel }\end{array}$ & $\begin{array}{l}\text { AEMD } \\
\text { parallel }\end{array}$ \\
\hline Continuous power $(\mathrm{kW})$ & 30 output & 30 input & 15 output & 15 input \\
\hline Peak power $(\mathrm{kW})$ & 55 output & 55 input & 30 output & 30 input \\
\hline Battery operating voltage (Vdc) & $325(200-450)$ & $325(200-450)$ & $325(200-450)$ & $325(200-450)$ \\
\hline Power factor & $>0.8$ & & $>0.8$ & \\
\hline Maximum current $(\mathrm{A})$ & 300 & 300 & 200 & 200 \\
\hline Precharge time--0 to 200Vdc (sec) & 2 & NA & 2 & NA \\
\hline Eff (10-100\% speed, $20 \%$ rated T curve) (\%) & $>97$ & $>93$ & $>97$ & $>93$ \\
\hline Torque ripple (\%) & NA & 5 & NA & 5 \\
\hline Output current ripple -peak to peak (\%) & $<=5$ & & $<=5$ & \\
\hline Input voltage \& current ripple (\%) & $<=5$ & NA & $<=5$ & NA \\
\hline Current loop bandwidth (kHz) & 2 & NA & 2 & NA \\
\hline Max fundamental electrical freq. (Hz) & 1000 & 1000 & 1000 & 1000 \\
\hline Ambient operating temperature $\left({ }^{\circ} \mathrm{C}\right)$ & -40 to +105 & -40 to +105 & -40 to +105 & -40 to +105 \\
\hline Storage temperature $\left({ }^{\circ} \mathrm{C}\right)$ & -50 to +125 & -50 to +125 & -50 to +125 & -50 to +125 \\
\hline Cooling system flow rate, max (gpm) & 2.5 & 2.5 & 2.5 & 2.5 \\
\hline Maximum coolant inlet temp. $\left({ }^{\circ} \mathrm{C}\right)$ & 70 & 70 & 70 & 70 \\
\hline Maximum inlet pressure (psi) & 25 & 25 & 25 & 25 \\
\hline Maximum Inlet pressure drop (psi) & 2 & 2 & 2 & 2 \\
\hline Useful life (years/miles) & $15 / 150,000$ & $15 / 150,000$ & $15 / 150,000$ & $15 / 150,000$ \\
\hline $\begin{array}{l}\text { Minimum isolation impedance-terminal to grd } \\
\text { (M ohm) }\end{array}$ & 1 & NA & 1 & NA \\
\hline $\begin{array}{l}\text { Minimum insulation impedance-terminal to } \\
\text { grd (M ohm) }\end{array}$ & NA & 20 & NA & 20 \\
\hline Maximum weight * & $5 \mathrm{~kW} / \mathrm{kg}$ & $35 \mathrm{~kg}$ & $5 \mathrm{~kW} / \mathrm{kg}$ & $22 \mathrm{~kg}$ \\
\hline Maximum volume* & $12 \mathrm{~kW} /$ liter & 11 liters & $12 \mathrm{~kW} /$ liter & 7 liters \\
\hline
\end{tabular}

Note: Changes are identified by bold type. 
APPENDIX C

EQUIPMENT USED IN TESTING AIPM

\begin{tabular}{|l|l|l|}
\hline Equipment item & Model & $\begin{array}{l}\text { Calibration } \\
\text { information }\end{array}$ \\
\hline & & \\
\hline Avtron Resistor Load Bank & K595D14442 & NA \\
\hline Bay Voltex Coolant Conditioner & MCHT-4050-E1 & NA \\
\hline & & \\
\hline DyneSystems 100-HP Dynamometer & EAC100-04836-01 & Calibrated 2/7/05 \\
\hline & & \\
\hline EMHP Power Supply & EMHP 300-200-42211 & NA \\
\hline & & \\
\hline $\begin{array}{l}\text { NWL Transformer Inductive } \\
\text { Choke }\end{array}$ & 103533 & NA \\
\hline & & \\
\hline Solectria Motor & AC55 & NA \\
\hline & & NA \\
\hline TFNMA Power Supply & EX354T & Due 8/27/05 \\
\hline & & \\
\hline Yokogawa PZ4000 Power Meter & 253710 & \\
\hline & & \\
\hline
\end{tabular}

NA-not applicable. 


\section{DISTRIBUTION}

Internal
1. D. J. Adams
2. C. W. Ayers
3. E. C. Fox
4. K. P. Gambrell

8. L. D. Marlino

9. S. C. Nelson

10. M. Olszewski

11-12. Laboratory Records

\section{External}

13. T. Q. Duong, U.S. Department of Energy, EE-2G/Forrestal Building, 1000 Independence Avenue, S.W., Washington, D.C. 20585.

14. G. L. Hagey, 501 Randolf Street, Williamsburg, Virginia 23185.

15. M. W. Lloyd, Energetics, Inc., 7164 Columbia Gateway Drive, Columbia, Maryland 21046.

16. S. A. Rogers, U.S. Department of Energy, EE-2G/Forrestal Building, 1000 Independence Avenue, S.W., Washington, D.C. 20585.

17. E. J. Wall, U.S. Department of Energy, EE-2G/Forrestal Building, 1000 Independence Avenue, S.W., Washington, D.C. 20585.

18. P. G. Yoshida, U.S. Department of Energy, EE-2G/Forrestal Building, 1000 Independence Avenue, S.W., Washington, D.C. 20585. 